\title{
XVII. YÜZYIL AZERBAYCAN ŞAİRİ TEBRIZLLİ KAVSÎ VE DÎVÂNI ÜZERİNE
}

\section{Farhad RAHIMI*}

Geliş Tarihi: A Ăustos, 2016

\section{$\ddot{\mathbf{O} z}$}

Kabul Tarihi: Aralık, 2016

$\mathrm{Bu}$ çalışmanın kapsamı, XVII. yüzyıl Azerbaycan şairlerinden Kavsî-i Tebrizî’nin hayatı, edebî kişiliği ve Dîvânı üzerinedir. Dönemin Azerbaycan edebiyatı anlatılmış, birçok tezkire ve başka eser taranarak Kavsî’nin hayatı ve edebî kişiliği verilmiş, Dîvânından seçilen beyitlerle dünya görüşü ortaya konulmuştur. Kavsî Dîvânının elde bulunan ve bulunmayan nüshaları tanıtılarak bunların geçtiği kaynaklar belirtilmiştir.

Anahtar Sözcükler: Kavsî-i Tebrizî, XVII. yüzyıl, Azerbaycan edebiyatı, Türkçe Dîvân.

\section{TEBRIZLLİ KAVSî THE AZERBAIJANI POET OF THE $17^{\mathrm{TH}}$ CENTURY AND HIS DÎVÂN}

\begin{abstract}
This work includes the life of Kavsî-i Tebrizî one of the Azerbaijan poets of the $17^{\text {th }}$ century, Literary Personality of him and the Dîvân of him. We firstly made a short review of $17^{\text {th }}$ Century Azerbaijan Literature; secondly, by reviewing many works and biographies written on the author's life, we tried to clarify many aspects of his life; we tried to clarify author's world view by giving examples from his Dîvân. We gave information about the Dîvân copies we have and do not have with the sources where copies are mentioned.
\end{abstract}

Keywords: Kavsî-i Tebrizî, $17^{\text {th }}$ Century, Azerbaijan literature, Turkish Dîvân.

\section{Giriș}

XVII. yüzyılda Türk dilinin gelişim süreci devam etmiştir. Bu yüzyıldan itibaren sözlü edebiyat yaratıcılığında bir artış görünmektedir. Folklor, yazılı edebiyatı fethetmiştir. Dönemin ünlü temsilcileri arasında Kavsî-i Tebrizî, Sâ'ib-i Tebrizî, Fedâî-i Tebrizî, Mesihî, Şah Abbas Sânî, Mevcî (Şeyhülislam Tebrizî), Tarzî Efşar, Derûnî, Te'sir, Melik Beg Avcı, II. Şah Abbas'ın tarihçisi olan ve II. Şah Safî’nin de vezirliğini yapan Mirza Tâhir Vahîd-i Kazvinî, Derviş Meselî, Muhammed Takî Dehharganî-i Tebrizî, Vâlî-i Kirmanî, Murtaza Kulu Han (Zafer) ve Muhammed Hüseyin Revanî’yi sayabiliriz (Rüstemova, 2004; Ertaylan, 1928; Hey'et, 1376).

\footnotetext{
*Dr.; Allame Tabatabai Üniversitesi, Tahran - İran, farhad_rahimi2007@ yahoo.com.
} 
Bu dönemde; önderi Azerbaycan şairi Sâ'ib-i Tebrizî sayılan "Sebk-i Hindî” adıyla ünlü edebî üslup, taklitçi şiire tepki olarak ortaya çıkmıştır. Şairlerin çoğu, Fuzûlî’nin etkisi altındadır. Nazım şekilleri içinde, kaside ön planda değildir ve gazele daha çok önem verilmiştir. Azerbaycan şairleri klasik üslupta eser vermekle birlikte, halk şiirinin biçimleri olan koşma, geraylı, tecnis ve bayatıda da yeteneklerini gösterip yüksek sanat örneklerini yaratmışlardır. Bu devirde Azerbaycan Türkçesinde şiir dilinin halk diline yakınlaşmasına büyük hizmetleri olan Sarı Âşık ve Âşı Abbas Tufarganlı gibi üstat sanatçılar yetişmişlerdir.

Köroğlu kahramanlık destanı da, XVI-XVII. yüzyıl Azerbaycan'da cereyan eden tarihisiyasi olaylarla ilgili olarak meydana çıkmıştır (Muhtaroğlu, 1992: 140).

\section{Kavsî’nin Hayatı}

Kavsî-i Tebrizî, XVII. yüzyıl Azerbaycan edebiyatı şairlerindendir. Onun hayatıyla ilgili fazla bilgi yoktur. Hacimli ve çoğu gazellerden (G) oluşan Türkçe Dîvânında; terkib-i bend (TB), terci-i bend (TC), müseddes (MS), muhammes (MH), murabba (MR) ve rubai (R) nazım şekilleriyle yazılmış şiirleri vardır. Kavsî, muhtemelen kimseyi övmekten yana olmadığı için kaside yazmamıştır.

Osmanlı tezkirelerinin malumu olmayan bu şairin şiirlerinden Tebrizli ve Şii olduğu anlaşı11ır.

N'ola Tebrizi ger Ḳovsī bèhişte ihtiyār ètse

Kim anung ḩāk-1 pākı sürmè-yi çėşm-i Sifāhāndur (TC.3.5/4)

Toprag̉dan götür men-i bī-ḳedri yā 'Elī

Ėy münḥeșir mürüvvet ü lüṭf ü 'ețā sanga (G.4/6)

Mirza Tâhir Vahîd-i Kazvinî’nin bağını öven terci-i bendi vardır (Rieu, 2008: 68-69; 1978: 209):

\section{Ol bāğda kim èyledi Mirzā onı zāhir}

Mirzā ki anung Ḥeḳ leḳebin èyledi Ṭāhir (TC2.5/1)

Mirza Tâhir Vahîd-i Kazvinî 1645 yılında II.Şah Abbas'ın (saltanatı: 1642-1666) tarihçisi olmuş, daha sonra Şah Süleyman (saltanatı: 1666-1694) ve Şah Sultan Hüseyin'in (saltanatı: 1694-1722) baş vezirliğini yapmıştır. Kendisi de şair olan Mirza Tâhir Vahîd-i Kazvinî’nin ölüm tarihi 1695 olarak kaydedilmiştir (Sâmî, 1893, C.IV: 2992). 
Dîvânındaki bir şiirinde Kavsî, kendisinin Uğurlu Han'ın kulu, Uğurlu Han'ın da Şah Süleyman'in kulu olduğunu söylemektedir. Şah Süleyman adıyla tahta çıkmış olan II.Safî, 1666-1694 yılları arasında hâkimiyet kurmuştur (Sâmî, 1893, C.IV: 2621). Kendisi de şair ve çok yiğit olan Uğurlu Han Ziyad oğlu Musahib ise, 1663 yılında II. Şah Abbas'ın hâkimiyeti zamanında Karabağ'ın beylerbeyi olmuştur (Devletabadî, 1370: 255-263). 1666-1667 tarihlerinde yani Şah Süleyman zamanında da, Gence'de hâkimiyet sürmüştür (Akpınar, 1994: 29). Kavsî’nin bu şiirde Gence şehrini övmesi, bir süre orada bulunduğunu da göstermektedir:

Havā-yı Gence ol firdövs-i șānī var başumda

Feġān kim nā-tevānlıg mānè‘ ü cem‘üm perīşāndur

Ug̉urlu Hูan Ziyād og̉lı Müṣāhib rūzgārında

Ki biz anung kulı ol bendè-yi Sulțān Süleymāndur (TC.3.5/5-6)

Bir gazelinde geçen "Şah Safî" de, II. Şah Safí yani Şah Süleyman olmalıdır. Beytin hükümdara övgü için yazıldığı anlaşılmaktadır:

'Erş-celāl Şāh Șefī kim hịimāyetüng

Dīn çevresine hịf ile çekmiş ḥișārlar (G.559/10)

Bütün bu bilgilerden anlaşılacağı üzere Kavsî XVII. yüzyılın ikinci yarısında yaşamış ve Sâ'ib-i Tebrizî’nin (1601-1676) de çağdaşı olmuştur.

Şimdi de Kavsî hakkında kaynaklardan elde edilen bilgilere göz atalım ve bu bilgilerin elimizde Türkçe Dîvânı bulunan Kavsî ile ilgisinin olup olmadığını inceleyelim:

1. Ali Şir Nevâî - Mecâlisü'n-Nefâ'is: Bu eserde geçen İsferayenli Kavsî’nin elimizde Türkçe Dîvânı bulunan Kavsî ile hiçbir ilgisi yoktur. Çünkü 1490 yılında tamamlanan bu eserde XV. yüzyılın şairleri kaydedilmiştir. Üçüncü Meclis’te yer alan bu şair, Nevâî ile görüşmüştür (Nevâî, 2001: 98; 1363: 73, 248, 460-461).

2. Fahrî-i Heratî - Fahrî Tezkiresi: Fahrî Heratî, Mecâlisü'n-Nefâ'is'i tercüme ederken eklediği tezkire bölümünde (yaz.1522) Heratlı olan Molla Kavsî’den bahsetmiş ve 1 beyit Farsça şiirini vermiştir. Fahrî Tezkiresinin yazılış tarihinin, üzerinde çalıştığımız Kavsî’den önceki döneme ait olduğu ve bahsedilen Kavsî’nin Heratlı olduğu göz önüne alınınca, Molla Kavsî’nin farklı bir Kavsî olduğu anlaşılmaktadır (Nevayi, 2001: xxxvı; 1363: 167).

3. Sâm Mirza - Tuhfe-i Sâmî: Bu eserde geçen ve Tebrizli olan Mevlânâ Kavsî, elimizde Türkçe Dîvânı bulunan Kavsî ile hiçbir ilgisi yoktur. Çünkü XVI. yüzyılda yaşayan Sâm Mirza, 
eserini 1550 yılında kaleme almıştır. Muhammed Ali Terbiyet gibi bazı bilginler Mevlânâ Kavsî’yi, Dîvânını çalıştı̆̆ımız Kavsî ile karıştırmışlardır. Dolayısıyla da bu bilginlerin eserini kaynak alan araştırmacılar aynı yanlışı yapmışlardır (Sâm Mirza Safevî, 1384: 254; Terbiyet, 1314: 310-311). Hatta bazı araştırmacılar Mevlânâ Kavsî’nin elimizde Türkçe Dîvânı bulunan Kavsî’nin babası olabileceğini hiçbir gerekçe göstermeden ileri sürmüşlerdir. Bu Kavsî, Fahrî Tezkiresi'nde geçen Molla Kavsî olabilir (Sâm Mirza Safevî, 1384: 254).

4. Hafiz Hüseyin Kerbelaî (öl.1588) - Revzâtü'l-Cinân ve Cennâtü'l-Cinân: 1567 yılında yazılan bu eserde Pir İmadeddin'in anlatıldığı kısımda, iki Kavsî'den bahsedilmektedir. Ancak bu iki kişiden bahsederken her ikisinin de vefat ettiğini ve yazar tarafından onlara Allah'tan rahmet dilendiğini öğreniyoruz (Kerbelaî, 1383: 163). Yani bunların hiçbirisi XVII. yüzyılda yaşamış olan ve elimizde Türkçe Dîvânı bulunan Kavsî olamaz. Muhammed Ali Terbiyet, Dânişmendân-i Azerbaycan adlı eserinde tarihlere dikkat etmeden bu iki Kavsî’ye de Kavsî maddesi altında değinerek bunları elimizde Türkçe Dîvânı bulunan Kavsî ile karıştırır (s.310-311). Bu yanlıştan dolayıdır ki Hamit Araslı da, eserin aslına başvurmadan aynı yanılgıya düşer. Terbiyet'in cümlesi şöyledir: "Derviş Hüseyin, Revzâtü'l-Cinân'da iki kişi baba ve oğul, İsmail Kavsî veled-i Alican Kavsî, Pir İmadeddin'i anlattığı kısımda zikretmiştir" (Terbiyet, 1314: 310-311). "İsmail Kavsî veled-i Alican Kavsî”, “İsmail Kavsî, Alican Kavsî'nin oğlu" demektir. Terbiyet bunun farkındadır, ancak sırasına dikkat edip "baba ve oğul" demek yerine "oğul ve baba" deseydi belki de bir büyük yanlışın önüne geçmiş olacaktı. Bu büyük yanlışı yine de H. Araslı yaparak Alican'ı oğul ve İsmail'i baba sanmıştır ve her yerde Alican Kavsî yazmaya başlamıştır (Arasl1, 1960: 506-516; 1998: 569-586). Hâlbuki Hafiz Hüseyin Kerbelaî’nin eserine bakıldığında, bunun böyle olmadığı açıktır. Bu yanlış bilgiden hareketle Yavuz Akpınar (Akpınar, 2002: 69-70; 1982b: 229), Mirali Seyidov, Paşa Kerimov, Ali Kafkasyalı, Cevad He’yet, Mümine Çakır gibi araştırmacılar da Kavsî’nin adını, Alican sanmışlardır. Birisi Baba olan Alican Kavsî, diğeri ise oğul olan İsmail Kavsî, elimizde Türkçe Dîvânı bulunan Kavsî değillerdir.

5. Takiye'd-din Muhammed bin Şerefe'd-din Ali Hüseynî-i Kaşanî - Hulâsatu'l-Eş'âr ve Zübdetü'l-Efkâr: 1577-1607 yıllar arasında yazılan bu eserde geçen Mevlânâ Kavsî, elimizde Türkçe Dîvânı bulunan Kavsî değildir. Kavsî ile ilgili bu eserde bulunan bilgiler, Tuhfe-i Sâmî'den aynen aktarılmıştır.

6. Sâ'ib-i Tebrizî - Beyaz: Eserde Kavsî'den 4 Farsça beyit örnek verilmiştir (Terbiyet, 1314: 310-311). Bu 4 beyitten 3'ü, Tahran/Melik 5604 numaralı elyazmasının Farsça kısmında bulunmaktadır (Kavsî, Dîvân, İran-Tahran Melik Millî Kütüphanesi, nr. 5604, s.253, s.271 ve s.329'un kenarlarinda).

TF̂P

Uluslararası Türkçe Edebiyat Kültür Eğitim Dergisi Sayl: 5/4 2016 s. 1773-1804, TÜRKIYYE 
7. Muammed Tahir Nasrabadî - Tezkire-i Nasrabadî (Tezkiretü'ş-Şu'arâ): Bu eser 1672-1698 tarihlerinde yazılmış ve Nasrabadî’nin çağdaşı olan şairleri kapsamaktadır. Bu eserde, iki Kavsî’den söz edilmektedir: Kavsî-i Şuşterî ve Kavsî-i Tebrizî. Nasrabadî’ye göre Kavsî-i Tebrizî İsfahan'a gelip Ağa Hüseyin Hansarî ile bahse girişmiştir. "Zü'l-cemaleyn" lakabı ile ünlü olan Ağa Hüseyin Hansarî (öl.1686), 1666'da Şah Süleyman Safevî’yi tahtına oturttuğu söylenen bilgin kişidir. Ayrıca bu eserde, Kavsî-i Tebrizî’nin boyunun bükülmüş olduğu belirtilmiş, ancak onun Türkçe şiir yazan bir şair olduğu belirtilmemiştir. Şairin belinin bükülmüş olduğu, elimizde bulunan Türkçe Dîvânda yer yer ifade edilmişse de; Ağa Hüseyin Hansarî ile ilgili hiçbir şey söylenmemiştir. Bu eserde örnek verilen 5 Farsça beyitten 3'ü, Tahran/Melik 5604 numaralı elyazmasının Farsça kısmında bulunmaktadır (s.219, s.329 ve s.367). Dolayısıyla Bu Kavsî, elimizde Türkçe Dîvânı bulunan Kavsî olabilir (Nasrabadî, 1361: 281-282).

8. AliKulı Vale Dağıstanî - Tezkire-i Riyâzu'ş-Şu'arâ: 1746-1747 yıllarında yazılan bu tezkirede iki Kavsî vardır (Dağıstanî, 1384: 1788, 1811):

a)- Mevlânâ Kavsî: Yaycılık yaptığı söylenir. Bu Kavsî, verildiği aynı şiir örneğinden dolayı, Fahrî Tezkiresi’nde adı geçen Molla Kavsî’dir.

b)- Kavsî-i Tebrizî: Bu kişinin şiirleri için örnek verilen 4 Farsça beyit Tezkire-i Nasrabadî'de, 1 Farsça beyit de Tuhfe-i Sâmî'de geçmektedir. Burada muhtemelen Tuhfe-i Sâmî'de olan Mevlânâ Kavsî, Tezkire-i Nasrabadî’de olan Kavsî-i Tebrizî ile karıştırılmıştır. Bunların dışında; verilen 4 Farsça beyitten 1'i, Tahran/Melik 5604 numaralı elyazmasının Farsça kısmında bulunmaktadır (s.245'in kenarında).

9. Mir Hüseyin Dost Sünbühlî - Tezkire-i Hüseynî: 1749 y1lında yazılan bu eserde, Kavsî-i Tebrizî adında beli bükük ve iyi bir şairden söz edilir ancak Türkçe şiir yazmasıyla ilgili hiçbir bilgi verilmez (Sünbühlî, 1292: 269). Tezkire-i Nasrabadî’deki Kavsî-i Tebrizî’ye ait 1 beyit burada da vardır. Bunun dışında örnek verilen 1 Farş̧a beyit (Sâ'ib'in Beyaz'ında da Kavsî’ye ait bu örnek verilmiştir) Tahran/Melik 5604 numaralı elyazmasının Farsça kısmında bulunmaktadır (s.253'ün kenarında).

10. Begdili Lutfali Beg Azer - Ateşkede-i Azer Tezkiresi: 1777 yılında kaleme alınan bu eserdeki Kavsî, makalemize konu olan şair değildir. Buradaki bilgiler, Fahrî Tezkiresi’ndeki Molla Kavsî’den aynen aktarılmıştır.

11. Nevvâb Sadîk Hasan Han Bahadır - Tezkire-i Şem'-i Encümen: 1874 yılında yazılan bu eserdeki Kavsî-i Tebrizî’ye ait bilgiler de, Fahrî Tezkiresi’ndeki Molla Kavsî'den alınmıştır (Bahadır, 1386).

TFरP

Uluslararası Türkçe Edebiyat Kültür Eğitim Dergisi Sayı: 5/4 2016 s. 1773-1804, TÜRKIYYE 
12. Nuru'l-Hasan - Nigâristân-i Sühan: 1874 yılında yazılan eserde, iki Kavsî’den bahsedilmektedir (Nuru'l-Hasan: 84):

a) Kavsî-i Tusî: Fahrî Tezkiresi'nde geçen Molla Kavsî olmalıdır. Örnek verilen şiir bunu göstermektedir.

b) Kavsî: Tarak gibi eşyalar yaptığı ve Ekber Şah'ın (saltanatı: 1555-1605) devlet adamlarından Han-1 Kelan'ın (Han-1 A'zam) hizmetinde bulunduğu söylenmektedir. Bu eserde ilk kez, Kavsî adlı kişinin Hindistan’a gittiğini öğrenmekteyiz.

13. Muhammet Muzaffer Hüseyin Saba - Tezkire-i Rûz-i Rûşen: 1877-1878 yıllarında yazılan bu eserde de, iki Kavsî’ den bahsedilmektedir (Saba, 1343: 666-667):

a) Kavsî-i Tusî: Bu kişi Fahrî Tezkiresi’nde geçen Molla Kavsî olmalıdır. Çünkü, örnek verilen şiir bunu göstermektedir.

b) Kavsî-i Tebrizî: İsfahan'da Ağa Hüseyin Hansarî'den ders aldığı, ayrıca Ekber Şah (öl.1605) zamanında Hindistan'a gelip Han-1 A‘zam’ın sohbetiyle onurlandığı kaydedilmiştir. Han-1 A'zam, Ekber şah (saltanatı: 1555-1605) ve Cihangir Şah'ın (saltanatı: 1605-1627) devlet adamlarından ve şairlerinden olup 1624 yılında vefat etmiştir (Sâmî, 1893, C.II: 1012-1013; C.III: 1857, 2019). 1605'te ölen Ekber Şah'ın şairlerinden olduğu söylendiğine göre, elimizde Türkçe Dîvânı bulunan Kavsî o değildir. Ayrıca Hindistan'la ilgili, elimizdeki Dîvânda da hiçbir şey söylenmemektedir. Burada muhtemelen, Tezkire-i Nasrabadî’ deki Kavsî-i Tebrizî ve Nigâristân-1 Sühan'daki Kavsî ile ilgili bilgiler birleştirilerek aktarılımıştır.

14. Aftab Ray-ı Lucknowî - Riyâzu'l-‘Arifîn: Kavsî hakkında verilen bilgilerin, AliKulı Vale Dağıstanî’nin Tezkire-i Riyâzu'ş-Şu'arâsı'ndan aktarıldığı anlaşılmaktadır (Lucknowî, 1361).

15. Mahmud Hidâyet - Gülzâr-i Câvîdân: Eserde, üç Kavsî’den söz edilmiştir. Bunlardan birincisi, Fahrî Tezkiresi'nde adı geçen Molla Kavsî'dir. İkincisi, Tezkire-i Nasrabadî'de adı geçen Kavsî-i Tebrizî’dir. Üçüncüsü ise, Nigâristân-i Sühan'da adı geçen Kavsî'dir (Mahmud Hidâyet: 1146).

16. Seyyid Azim Şirvanî - Tezkiretü'ş-Şu'arâ: 1875-1885 yıllar arasında kaleme alınan bu tezkirede, ilk kez elimizde Türkçe Dîvânı bulunan Kavsî’nin Türkçe şiirlerinden birçok örnek verilmiş ancak hayatıyla ilgili yalnız Tebrizli olduğu söylenmiştir. Şirvanî’nin eserinin başka bir yerinde Kavsî’ye ait verdiği Farsça örnek beyit ise, Fahrî Tezkiresi'ndeki Molla Kavsî’ye aittir (Bayram, 2005). 
17. Charles Rieu - Catalogue Of The Turkish Manuscripts İn The British Museum: Londra, British Museum'daki Kavsî Dîvânını ilk kez Rieu tespit etmiştir. 1888 yılında kaleme aldığı bu eserde Kavsî'nin Tebrizli ve Şii olduğunu, Mirza Tâhir Vahid Kazvinî’nin bağını bir terci-i bend ile övdügünü, Tezkire-i Nasrabadî’de geçen Kavsî’nin de Kavsî-i Tebrizî olabileceğini ve bu Dîvânın hem baştan hem de sondan eksik olduğunu söylemiştir (Rieu, 1978: 209; 2008: 68-69).

18. Şemseddin Sâmî - Kâmusü'l-A'lam: 1888-1898 y1lları arasında yazılan bu eserde, Fahrî Tezkiresi’nde geçen Molla Kavsî'den (aynı şiiri vermiştir) başka (Kavsî adıyla verdiğine göre, Ateşkede-i Azer'den almış olabilir), bir de Bağdatlı ünlü bir hattat olup 1590'da vefat eden Kavsî'den bahseder. Bunların hiçbirisinin, elimizde Türkçe Dîvânı bulunan Kavsî olmadığını söyleyebiliriz (Sâmî, 1893, C.V: 3740).

19. Feridun Bey Köçerli - Azerbaycan Edebiyatı Tarihi Materyalleri: Yazar, 1925 yılında eline geçen Kavsî’nin Türkçe Dîvânı üzerinden şairin bazı gazellerini verir. Hayatıyla ilgili bilgiler yanında bazı şiirlerini de açıklamaya çalışır. Kavsî’nin terci-i bend yazdığı Uğurlu Han Ziyad oğlunun 1766-1776'da hanlık yaptığını, dolayısıyla da Kavsî’nin Molla Penah Vâkıf'in çağdaşı olduğunu belirtir. Daha önceden de gördüğümüz gibi, bu bilgiler doğru değildir. Kavsî-i Tebrizî, XVII. yüzyılın ikinci yarısında yaşamıştır. Köçerli’nin elinde bulunan Dîvânın bugün nerede olduğu belli değildir (Köçerli, 1925: 175-187).

20. Selman Mümtaz - Azerbeycan Edebiyatı: Yazar 1925 yılında, Kavsî’nin Türkçe şiirlerinden bir kısmını önsözle birlikte yayınlamıştır (Mümtaz, 1925).

21. İsmail Hikmet Ertaylan - Azerbaycan Edebiyatı Tarihi: Yazar, Kavsî’nin bazı Türkçe şiirlerini tahlil etmeye çalışır (Ertaylan, 1928: 196-209).

22. Muhammet Ali Terbiyet - Danişmendân-ı Azerbaycan: 1935'de yazılan eserin “Kavsî” maddesinde, önce Tuhfe-i Sâmî'deki sonra da Tezkire-i Nasrabadî'deki bilgiler aktarılarak bu iki Kavsî karıştırılmıştır. Hafiz Hüseyin Kerbelâî'nin Ravzâtü'l-Cinân ve Cennâtü'l-Cinân'ındaki iki Kavsî de, elimizde Türkçe Dîvânı bulunan Kavsî ile karıştırılmıştır. Terbiyet; elinde Kavsî’nin Farsça ve Türkçeden oluşan 6000 beyitlik bir Dîvânının bulunduğunu söylese de, bugün bu Dîvânın nerede olduğu belli değildir. Ancak elindeki Dîvândan örnek verdiği ve Sâ'ib'in de adının geçtiği Farsça bir beyit, İran-Tahran Melik Millî Ktp.'nde bulunan 5604 numaralı elyazmasının Farsça kısmında da bulunmaktadır (s.272'nin kenarında). Terbiyet; Sâ'ib'in Beyaz adlı eserinde Kavsî'den birkaç beyit seçip aktardığını söyleyerek, o beyitlerden bir kaçını (Farsça) zikreder. Bunların içinde, Tezkire-i Nasrabadî’deki Kavsî-i Tebrizî’ye ait bir beyit ile Tezkire-i Hüseynî’deki Kavsî-i Tebrizî’ye ait bir beyit de 
bulunmaktadır (Terbiyet, 1314: 310-311; Kavsî, Dîvân, İran-Tahran Melik Millî Kütüphanesi, nr. 5604).

23. Muhammed Ali Musahibi-i Nainî - Tezkire-i Medinetü'l-Edeb: 1940'da yazılan bu eserdeki Kavsî ile ilgili bilgiler, Tezkire-i Nasrabadî’deki Kavsî-i Tebrizî’den alınmıştır (Nainî, 1376: 968).

24. Mehmet Nail Tuman - Tuhfe-i Nailî: 1949'da yazılan bu eserin “Kavsî” maddesinde, elimizde Türkçe Dîvânı bulunan Kavsî’den bir beyit örnek verilmiştir. Ancak onunla ilgili bilgilerdeki "Kavsî Çelebi, Bağdatlı, Hattat, vefatı 1590” ifadesi, Şemseddin Sâmî'nin Kâmusü'l-A'lam'ındaki Bağdatlı Kavsî'yi işaret etmektedir (Tuman, 2001: 832).

25. Hamit Araslı - XVII-XVIII. Asr Azerbaycan Edebiyatı Tarihi; Qövsi Tebrizi, Azerbaycan Edebiyatı Tarihi ve Problemleri; Gövsi Tebrizi, Seçilmiş Eserleri; Azerbaycan Edebiyatı Tarihi: 1956 yılında kaleme aldığı "XVII-XVIII. Asr Azerbaycan Edebiyatı Tarihi” ve "Qövsi Tebrizi, Azerbaycan Edebiyatı Tarihi ve Problemleri” adlı eserlerinde Kavsî'den bahsetmektedir. Yazar, 1958 yılında “Gövsi Tebrizi, Seçilmiş Eserleri” adıyla Londra ve Gürcistan nüshalarına dayanarak yayınladığı bir başka çalışmasında ise, onun Türkçe Dîvânının büyük bir kısmını yayınlamıştır. “Azerbaycan Edebiyatı Tarihi” adlı eserde de onunla ilgili bilgiler yanında bazı şiirleri de açıklanmaktadır. Ancak Kavsî adıyla ilgili yanlış bilgiler verilmiştir. Terbiyet'in yanlışı yüzünden Araslı da; Hafiz Hüseyin Kerbelaî’nin Revzâtü'l-Cinân ve Cennâtü'l-Cinân'ındaki iki Kavsî'yi, elimizde Türkçe Dîvânı bulunan Kavsî ile karıştırmıştır. Üstelik Revzâtü'l-Cinân ve Cennâtü'l-Cinân'daki iki Kavsî’yi yani oğul ve babayı da birbirine karıştırarak elimizde Türkçe Dîvânı bulunan Kavsî’ye Alican adını takmıştır (Arasl1, 1960: 506-516; 1998: 569-586).

26. Abdürresul Hayyampur - Ferheng-i Sühanverân: 1961'de yazılan bu eserde, 5 Kavsî’den bahsedilmektedir (Hayyampur, 1340: 477):

a) Kavsî-i İsferayenî: Mecâlisü’n-Nefâ'is’te adı geçen İsferayenli Kavsî'dir.

b) Kavsî-i Tebrizî: Tuhfe-i Sâmî'de geçen Mevlânâ Kavsî ve Tezkire-i Nasrabadî’de geçen Kavsî-i Tebrizî olduğu söylenerek bu iki Kavsî’nin aynı kişiler olduğu sanılmıştır.

c) Kavsî-i Şuşterî: Tezkire-i Nasrabadî’de adı geçen Kavsî-i Şuşterî’ dir.

ç) Kavsî-i Herevî (Heratlı): Fahrî Tezkiresi’nde geçen Molla Kavsî'dir (tezkirelerde Kavsî-i Tusî de denilmiştir).

d) Kavsî: Nigâristân-i Sühan'da adı geçen Kavsî’dir. 
27. Mirali Seyidov - Qövsi Tebrizi: 1963'te yazılan bu eserde, şairin hayatıyla ilgili bilgiler daha çok H. Araslı'ya dayanmaktadır. O da yanlışlıkla Kavsî’ye Alican demiştir. Eserde Kavsî’nin sosyal düşünceleri, insana ve insan sevgisine verdiği önem ile şiirinin sanatsal özellikleri; Dîvânı incelenerek açıklanmaktadır. (Seyidov, 1963).

28. Aga Büzürg Tahranî - Ez-Zeria ila Tasanifi'ş-Şi'a: 1970'de yazılan eserde, Dîvânı ya da şiiri bulunan altı Kavsî’den söz edilmektedir (Tahranî, 1970: 892-893):

a) Kavsî-i İsferayenî: Mecâlisü’n-Nefâ'is’te adı geçen İsferayenli Kavsî.

b) Kavsî-i Tebrizî: Tuhfe-i Sâmî'de geçen Mevlânâ Kavsî.

c) Kavsî-i Tebrizî: Tezkire-i Nasrabadî’ de adı geçen Kavsî-i Tebrizî.

ç) Kavsî-i Tebrizî: Revzâtü'l-Cinân ve Cennâtü'l-Cinân'daki Alican Kavsî'nin oğlu İsmail Kavsî’ dir. Burada Alican yerine, yanlışlıkla Alihan yazılmıştır.

d) Kavsî-i Şuşterî: Tezkire-i Nasrabadî’de geçen Kavsî-i Şuşterî.

e) Kavsî-i Herevî (Heratlı): Fahrî Tezkiresi’nde geçen Molla Kavsî'dir (tezkirelerde Kavsî-i Tusî de denilmiştir).

29. Ahmet Münzevî - Fihrist-i Nüshahâ-yı Hattî-i Fârsî: 1971'de yazılan eserin 'Kavsî-i Tebrizî Dîvânı” başlıklı kısmında, iki nüsha yani İran-Tahran Melik Millî Ktp.'nde bulunan 5604 numaralı nüsha ile Pakistan Dânişgâh-1 Pencab'da 699 pi VI 165 (572 f) numara ile kayıtlı nüshayı kaydetmiştir (Münzevî, 1350: 2488).

30. Aziz Devletabadî - Sühanverân-ı Azerbaycan: 1976'da yazılan eserde; Tuhfe-i Sâmî'de geçen Mevlânâ Kavsî, Tezkire-i Nasrabadî'de geçen Kavsî-i Tebrizî’den haklı olarak ayrılmıştır. Tezkire-i Nasrabadî’deki Kavsî-i Tebrizî'nin, elimizde Türkçe Dîvânı bulunan Kavsî-i Tebrizî olduğu belirtilmiştir. Münzevî’nin işaret ettiği Kavsî-i Tebrizî Dîvânının iki nüshası ile Hacı Hüseyin Nahçıvani'ye ait Tebriz Millî Ktp.'ndeki yaklaşık 4700 beyitlik Türkçe şiirden oluşan ve 1675 yılında (yani Kavsî’nin hayatta olduğu bir zamanda) Asker bin Hacı Ali Tebrizî tarafından istinsah edilen nüsha da zikredilmiştir (Devletabadî, 1377: 601-602).

31. Azerbaycan Sovet Ansiklopediyasi: 1979'da yazılan eserin “Qövsi Tebrizi” maddesinde, Kavsî ile ilgili kısaca bilgi verilir. Bu bilgiler daha çok H. Araslı'nın aktardıklarına dayanmaktadır. Burada da, Alican adı yanlışlıkla kullanılmıştır (Azerbaycan Sovet Ansiklopediyasi, 1979: 223).

32. Yavuz Akpınar - Türk Dili ve Edebiyatı Ansiklopedisi, Azeri Edebiyatı Araştırmaları, İslam Ansiklopedisi: 1982'de, Türk Dili ve Edebiyatı Ansiklopedisi'ne 
yazdığ1 "Kavsî-i Tebrizî, Alican" maddesinde, Kavsî-i Tebrizî Dîvânının İstanbul Ün. Ktp. 5478'de kayıtlı nüshasından bahsetmiş̧tir. Bu nüshanın başı eksiktir. 1994'te kaleme aldığı Azeri Edebiyatı Araştırmaları'nda da Kavsî geçer. 2002'de yazdığı İslam Ansiklopedisi'ndeki “Kavsî-i Tebrizî” maddesinde ise, Kavsî Dîvânının 4 nüshasından (British Museum, Tiflis'teki Gürcistan Devlet Ktp., Terbiyet ve Köçerli'nin elinde bulunan Dîvân) söz eder. Burada Kavsî ile ilgili verilen bazı yanlış bilgiler (Alican adı ve dede-baba-torun konusu gibi), H. Araslı'dan aktarılmıştır (Akpınar, 1982b: 229; 1994: 29; 2002: 69-70).

33. Hamîde Reiszâde - Dîvân-ı Kavsî: 1997 yılında, Kavsî’nin Türkçe Dîvânını 4 nüshadan yani Londra, Millî Tebriz, Melik (nr.5604) ve hiçbir bilgi vermediği Almanya nüshalarından yararlanarak bir önsözle birlikte İran'da (Arap alfabesiyle) yayınlamıştır (Reiszâde, 1376).

\section{Paşa Kerimov - Qövsi Tebrizi Divan, Qövsi Tebrizi Seçilmiş Eserleri, XVII Asr} Azerbaycan Lirikası (Antologiya): 2005 yılında, Kavsî Dîvânının tenkitli metnini 6 nüshayı karşılaştırarak (Tiflis, Londra, İstanbul Ün. ve Bakü nüshalarını temel alıp; Millî Tebriz ve Melik (nr.5604) nüshalarından da yararlanarak) bir önsözle birlikte yayınlar. O da H. Araslı'nın bazı yanlış tespitlerini yinelemiştir (Kerimov, 2005; 2008).

35. Mümine Çakır - "Kavsi, Hayatı, Edebî Kişiliği ve Divanı (inceleme-tenkitli metindizin)": 2008 yılında tamamlanan bu doktora tezinde, önce Kavsî’nin hayatı ve edebî kişiliği ile ilgili bilgi verilmiştir. Bu bölümlerde, H. Araslı kaynaklı yanlışlıklar yinelenmiştir. Daha sonra Dîvânın tenkitli metni, 9 nüsha karşılaştırılarak (Londra, Tiflis, Tebriz ve İstanbul Ün. nüshaları esas alınıp; Ankara Millî Ktp., Medine, Bakü, Süleymaniye Ktp. ve Malatya İl Halk Ktp. (daha sonra Konya Müzesi Ktp.'ne taşındı) nüshalarından da yararlanılarak) ortaya konmuştur. Bunlardan başka, ulaşılamadığı kaydedilen Melik (nr.5604) ve Pakistan nüshalarından da sözedilmiştir. Tezin en önemli tarafı, Kavsî Dîvânında kullanılan edebi sanatlar ve Dîvânın içerik yönüyle incelenmesidir. Dîvândaki birçok şiire tahlil ve açıklama getirilmiştir (Çakır, 2008).

Kavsî'den bahseden başka araştırmacılardan 1969'da Mir Celal ve Firidun Hüseynov (Celal, 2000: xxxv111), 1979'da Cevad Hey'et (Hey'et, 1376), 1979'da M. Fuad Köprülü (Köprülü: 138), 1982’de Aliyar Saferli ve Halil Yusuflu (Saferli, 1992: 254-257; 1376: 313), 1988'de Muhammed Deyhim (Deyhim, 1367: 537-540), 2002'de Ali Kafkasyalı (Kafkasyal1), 2002'de Ahmet Pirverdioğlu, 2004'te Azade Rüstemova (Rüstemova: 477-478), 2005'de Muhammed Riza Kerimî (Kerimi, 1384: 483-494)ํㅡㄹ , Muhammed Ali Hüseyni (Kerimov, 2008),

\footnotetext{
${ }^{1} \mathrm{O}, 1184$ y1lında istinsah edilen ve Tebriz'de bulunan başka bir nüshadan söz etse da tam nerede olduğunu
} söylememiştir. 
Riza Hemraz (Hemraz, 1389) ve Muhammed Emin Sultanu'l-Kurrâî (Sultanu'l-Kurrâî 1389) gibilerini sayabiliriz.

Kaynaklardan da görüldügü gibi, Kavsî adıyla bir hayli şair bulunmaktadır: Mecâlisü'nNefầ'is'deki İsferayenli Kavsî, Fahrî Tezkiresi'ndeki Molla Kavsî (Kavsî-i Tûsî veya Kavsî-i Heratî), Tuhfe-i Sâmî'de geçen ve Tebrizli olan Mevlânâ Kavsî, Revzâtü'l-Cinân ve Cennâtü'lCinân'daki Alican Kavsî ve onun oğlu İsmail Kavsî, Tezkire-i Nasrabadî’daki Kavsî-i Şuşterî ve Kavsî-i Tebrizî, Nigâristân-i Sühan'daki Kavsî, Kâmusü'l-A'lam'daki Bağdatlı Kavsî ve elimizde Türkçe Dîvânı bulunan Kavsî. Türkçe Dîvân sahibi Kavsî, Tebrizli olduğuna göre; İsferayenli Kavsî, Kavsî-i Şuşterî ve Bağdatlı Kavsî olamaz. Kendisinden farklı tarihlerde yaşamış Fahrî Tezkiresi’ndeki Molla Kavsî, Tuhfe-i Sâmî'de geçen Mevlânâ Kavsî, Revzâtü'lCinân ve Cennâtü'l-Cinân'daki Alican Kavsî ve onun oğlu İsmail Kavsî ile Nigâristân-i Sühan'daki Kavsî de değildir. Tuhfe-i Sâmî'de geçen Mevlânâ Kavsî ile Fahrî Tezkiresi'ndeki Molla Kavsî’nin aynı kişiler olması ihtimali vardır. Bu konuda kesin bir hükme varabilmek için bu iki kişinin şiirlerinin bulunup karşılaştırılması gerekmektedir. Elimizde Türkçe Dîvânı bulunan Kavsî hakkında her ne kadar bir Türk şairi olduğu ve Türkçe şiirlerinin bulunduğu söylenmemekteyse de, Nasrabadî’ deki Kavsî-i Tebrizî o olmalıdır.

\section{KAVSî'NİN EDEBÎ KİȘiLİĞi}

Burada, kaynakların Kavsî için söyledikleriyle (Seyidov, 1963; Arasl1, 1960: 506-516; Arasl1, 1998: 569-586; Kerimov 2009: 57-67; Köçerli 1925: 175-187; Çakır 2008; Pirverdioğlu; Caferoğlu 1953: 19; Öztekin 2010:101-102) onun Türkçe Dîvânından yararlanarak edebî kişiliği ve dünya görüşünü aydınlatmaya çalışacağız.

Şah İsmail zamanında başkent Tebriz iken, Şah Tahmasp zamanında Kazvin'e ve I. Şah Abbas zamanında ise İsfahan'a taşınmış ve böylelikle saraya mensup olan dîvân edebiyatı temsilcileri başkente gitmek gereğini duymuşlardır. Kavsî İsfahan'da olduğu zamanlarda Tebriz'in özleminden yanmıştır:

Tebriz cežbesi yahamı dutmış aparur

Ḳovsī egerçi dāmenümi İṣfahān dutar (G.45/7)

Çünkü onun gönlünü yalnız Tebriz açabilir:

Tebriz açar gönglümi Ḳovsī ger açılsa

Her çend ki firdövs-i Șifāhāna yètişmez (G.220/11)

Tebriz, İsfahan şehrinin Ka‘besidir:

Ḳovsī gerek ki Ke‘be diyüb iḳtidā ḳıla 
Tebriz küllesine Șifāhān dèdükleri (G.532/7)

Kavsî, uçmağa gitmek yerine mübarek (temiz) toprağı İsfahan'in gözüne sürme olan Tebriz'e gitmeyi yeğler:

N'ola Tebrizi ger Kovsī bèhişte iḩtiyār ètse

Kim anung ḩāk-1 pāk1 sürmè-yi çėşm-i Sifāhāndur (TC.3.5/4)

Kavsî, Azerbaycan Türk edebiyatının gelişmesinde önemli rol oynayan ve XVII. yüzyılda Fuzûlî ekolünü sürdüren şairler arasında yer alır. Çünkü bu yüzyılda yazılan gazellerin çoğunda, Fuzûlî biçemi ve dilinin korunması büyük bir üstatlık sayılmıştır. Azerbaycan halk edebiyatının gelişmesi, XVII-XVIII. yüzyıl Azerbaycan yazı dili ve edebiyatı üzerinde oldukça büyük bir etki yapmıştır. Bu dönemde yetişen Mesihî, Sâ'ib ve Kavsî; dil bakımından hep bu edebiyattan esinlenmişlerdir. Fuzûlî geleneğine oldukça bağlı kalan Kavsî, çağdaşı şairlerden bir adım öndedir. Zengin halk edebiyatı servet ve motiflerinden yararlanmasını bildiği gibi, şiir tekniğinde de üstattır.

Kavsî, Türk dili için sorumluluğunun farkında olarak Türkçe şiirleri ile bütün dünyayı fethedeceğini söylemektedir:

Ėtmek içün Türk neẓmi-yle müseḩ̧er 'ālemi

Tapdılar erbāb-1 me‘nī bilmenem handan beni (G.474/10)

Kavsî’nin “görgec” redifli gazeli, Fuzûlî’nin aynı redifli gazeline naziredir. Bilindiği gibi, Fuzûlî de şiirini yazarken Nevâî’nin aynı redifli gazelini örnek almıştır:

Elden gėderem serv-i hürāmānuñ̂̀ görgec

Dilden düşerem ġunça-yı ḩendānunĝ̀ görgec (G.36/1)

Kavsî’nin Nevâî, Fuzûlî ve Vahîd Kazvinî’nin gazellerine yazdı̆̆ı nazirelerin çoğunda, bu şairlerin beyitlerinden birer mısra örnek verilerek onların adları anılmıştır:

Beni mest ètdi Füżūlì kimi bu söz Ḳovsī

Kim olım mest dutım dāmen-i dilber güstāḥ (G.38/9)

Ne yahşs söylemiş Ḳovsī Veḥīd-i pāk-gövher kim

Beni yandurdı bir āteş ki düşmenden ırag̉ olsung (G.272/11)

Ḳovsī bu ol gezel-i neġz-i Füżūlīiür kim

Nece āh ėylemeyim āh yanubdur cigerüm (G.329/8)

TF̂R

Uluslararası Türkçe Edebiyat Kültür Eğitim Dergisi Sayı: 5/4 2016 s. 1773-1804, TÜRKIYYE 
Kavsî’nin “göz” redifli gazeli, Nevâî’nin aynı redifli gazeline naziredir. Bu naziresinde, Nevâî’nin adını anıp bir beytini zikreder:

Bu hemān re'nā gezeldür kim Nevāyī söylemiş

Sürme-gūn tünlerde hicrān şāmı tut bīdār göz (G.221/10)

Ol kelāmıdur Nevāyīnüng bu Ḳovsī kim dėmiş

Bes ki tofrag oldı 'èşküng deştide āvāreler (G.158/8)

Şairin “gel” redifli gazeli, Nesimî’nin aynı redifli gazelini anımsatmaktadır:

Sāḳiyā bag̉rum mėy-i gülgūn içün ḳan oldı gel

Ṣebr èvi sensiz tezelzül buldı vīrān oldı gel (G.293/1)

Yukarıda adı geçen şairlerden etkilenen Kavsî, Vâkıf'ı da etkilemiştir. Hatta onunla birlikte, Azerbaycan şairlerinin önde gelenlerinden sayılır.

Afyon Mevlevihanesi şeyhlerinden "Semâ̂̂” mahlaslı Mehmed Çelebi’nin (öl.1550) bir gazeline nazire yazarak, "Gönüldendir şikâyet kimseden feryadımız yoktur” biçimindeki ünlü mısrası da aynen kendi gazeline almıştır. Bu da onun Osmanlı şairlerinin şiirlerine yabancı olmadığını gösterir:

Bu ol şīīn gezeldür kim dèmiş bir sāḥir-i māhir

Göngüldendür şikāyet kimseden feryādumuz yoḳdur (G.137/9)

Kavsî'nin bir gazelinde, Ağa Razî’nin adı geçer:

Bu ol ġezel cevābı ki Aḳa Reżī dèdi

Bu yolı başa aparuram bir ayag ilen (G.393/12)

XVIII. yüzy1l dîvân şiirinin ünlü temsilcilerinden Çelebizâde Âsım'ın Kavsî'nin bir mısraına yazdığ

Dimiş bu mıṣra'‘ Kavsīi dilimden ey 'Āṣım

Zamāne her kimi kim yaḳdı ben ḩarāb oldum

$$
\text { Çelebīzāde ‘'Āṣım }
$$

Onun Şii olduğu, şiirlerinden anlaşılmaktadır:

Sipèhr-i nā-cavān-merdüng sitīzinden ne ġem Ḳovsī

Ki lüṭf-i şāh-1 merdān Ḥèyder-i Ṣefder hịṣārumdur (G.140/7)

Toprag̉dan götür men-i bī-ḳedri yā ‘Elī

Tर्ph

Uluslararası Türkçe Edebiyat Kültür Eğitim Dergisi Sayı: 5/4 2016 s. 1773-1804, TÜRKIYYE 
Ėy münḥeșir mürüvvet ü lüṭf ü 'ețā sanga (G.4/6)

Āstānuñg daşına Ḳovsī kimi yüz șürmege

Baġrumı āb ètdi yā şāh-1 Horāsān intizāār (G.170/9)

Bir āşnā ki Ke‘bè-yi meḳṣūda Ḩıżr ola

Ḳovsī gerīb-i hāāk-1 Ḩorāsāndan isterem (G.357/7)

Horasan şahı, Horasan'ın garibanı, Şiilerin inandıkları 12 İmamdan sekizincisi yani Meşhed şehrinde yatan İmam Rıza'dır.

Onun çocuk sahibi olmadığı, bu şiirlerinden anlaşılmaktadır:

Ḳovsī yahardı nesl gemi cāvdān beni

Yandurmasaydı miṣre'-i rengīn çırāg̉umı (G.490/9)

Kavsî, sade bir yaşam sürdürmüştür:

Būryā ferşüm ü èvüm mescid

Ne gözel kedhudālığum vardur (G.169/6)

Tasavvuf anlayışına göre (vahdet-i vücûd), bütün varlıklar, hakikatin tecellisidir. İnsan da mutlak ruhun bir parçasıdır ve bir gün ona kavuşacaktır:

Her ne var 'ālemde bir birden beter ser-geştedür

Kețre ‘ümmān aḩtarur 'ümmān ne ister bilmenem (G.365/6)

Ėy dem-ā-dem ėyleyen teklïf-i mescid Ḳovsīye

‘Āşı̣̣-1 bì-tābda ỉmān ne ister bilmenem (G.365/14)

Aşk söz konusu olduğunda, sevgilinin zulmünden ve acımasızlığından yakınır:

Düşmenini kimse sevmez bilmenem yā Reb n'içün

Ben seni ‘ālemce èy bī-reḥm-i hūn-ȟ̃ār isterem (G.367/3)

Kavsî, sevgili için ateşlere düşer ve bu ateş -tıpkı Semender gibi- onu besleyip yaşatır. Bilindiği gibi, Semender de ateşte yanıp kül olduktan sonra o küllerin korlarıyla yeniden dirilmektedir:

Her çend yandung odlara Kovsī usanmadung

Āhir sen èy ot èvlü semender misen nesen (G.385/10)

Şiirleri, güzelliğini ve letafetini sevgilinin güzelliğinden alır:

Ola ger Ḳovsīye menẓūr gül-i rühssārung 
Neẓm-i rengīn ile dünyānı gülistān èyler (G.65/9)

Müjgān gibi deler cigerin seng-i ḩārenüng

Her mișre‘üm ki kașung ucından ișāredür (G.80/10)

Ancak insan güzelliği, yalnız dış görünüşüyle değil zengin iç dünyası ve manevi halleriyle de ölçülür. Görünüşe aldanıp manayı anlamayanlar için kavuşma, bir körün çıra istemesine benzer:

Gözi șūret gören me‘nīden āgāh olmayan gāâil

Eger veṣl istese bir kūra benzer kim çırāg ister (G.89/8)

Bu șūret-hānede her șūret-i bī-cāna aldanma

Ki çoḳdur bü'l-hevesler 'āşıḳ-1 ḥeyrān libāsında (G.449/4)

Dolayısıyla, aşığın giyimine değil iç dünyasına bakılmalı ve değer verilmelidir:

Zinhār kem libāsına kem bahıma 'āşıkung

Kim dāg̉ung altı ḳırmızıdur üsti ḳaradur (G.80/7)

Kavsî, dünyanın malına mülküne gönül bağlamaz. Görünüşteki güzellikle işi yoktur:

‘Āşıḳam ben dövlet ü māl u menālı n'èylerem

Berg ü berden yummışam göz şāḩ u bālı n'èylerem

Yèg gelür bir gunça-yı mestūr yüz gülden banga

Yār-1 șāhịib-dil gerek ṣāḥib-cemālı n'ėylerem (G.339/1-2)

Gerçek yani doğru sözlü sadık âşık ise azdır:

Çoḳdur heves erbābı velī 'āşıḳ-1 șādıḳ

Azdur nėce kim neġmè-yi ter çok eser azdur (G.181/2)

Kavsî, gerçek sevgi ve dostluğun bulunmayışından yakınır:

Hemīn iksīir tek bir ad esşitdüm āşnālığdan

Ḥeḳiḳet menzilinde kāfirem ger āşnā gördüm

Mehebbet șāf u bì-ġeș kīmyādur düşse bil ḳedrin

Ki çoḳ bī-müdde‘ālar çèhresinde müdde‘ā gördüm (G.338/3-4)

Fuzûlî’nin "söz" redifli gazeline yazdığı nazirede, doğru ve etkili sözün ne olduğunu şöyle açıklar:

Dīdè-yi bī-nūrdur te'șīrsiz güftār kim 
Gövher-i gelțān eșerdür ebr-i gövher-bār söz (G.222/6)

Kavsî, halk yaratıcılığının pınarından ve sözlü edebiyatından beslenen bir şairdir. Dîvân edebiyatı anlayışının yanında, halk söyleyişini de kullanmıştır. Halk ifadelerine, atasözlerine, destan ve efsanelerin kahramanlarına s1k s1k başvurur. Bunlardan biri de, Hızır'dır. Azerbaycan halk destanlarında Hızır, insanlara özellikle de âşıklara yardım elini uzatır:

Ėy Hुıżr ‘èşk kūyına yārung apar beni

Kim bes ki serḩoşam reh-i mėy-ḩāne bilmenem (G.304/4)

Şiirlerinde, atasözlerinden de yararlanmıştır:

\section{Cahānda her kişi öz ekdügin biçer āḩir}

Nedāmetini yaman sözlerin çeker düşmen (G.40/4)

Teshīir-i zülf-i yārı ṣebādan diler göngül

Okșar anga ki özge eliyle ilan dutar (G.45/6)

Şerāb hūn-1 ciger def'ine ne fāyide sensiz

Boyung belāsın alım ḳanı ḳan ile yumag̉ olmaz (G.206/2)

\section{Bir ḳapu bag̉layan birini bī-gümān açar}

Sāḳi şerāb esirger ise ḳan esirgemez (G.223/2)

Sīnede gönglüm sarāyın rövşen èyler şem‘'i dāg

Öz ayaġı altına her çend 1şı̀ vèrmez çırāg (G.245/1)

Erinmeyince göngül bī-fürūġdur me'nī

Söz ile vèrmez 1şı่̀ şem'-i bezme yag̀ gerek (G.285/8)

Öz bābını her kimse her yèrde tapar Ḳovsī

Ben her yana kim gètdüm dīvāneye tuş geldüm (G.313/6)

Tapdug da şem‘-i veṣlin anung göz götürme kim

Kimse geçen güni tapabilmez sorāg ilen (G.393/9)

Egerçi doġnya meşhūrdur zavāl olmaz

Fegāan ki dūstları dog̉nı söz èder düşmen (G.401/2)

Hețā diyer ol ki diyer bir gül ile yaz olmaz

Ki oldı bir nefes ol nov-bahār kāmumca (G.431/5) 


\section{Bir arha kim gele su var ümīd bir de gele}

Olursa ‘ömr, olur bir de yār kāmumca (G.431/6)

Yètmeyen söz sūzına şūrın ne bilsüng me‘nīnüng

Ag̀zı şīīn èylemez ḥelvā dèmek ḥelvā gibi (G.482/8)

Şiirinde sade ve akıcı bir dil kullanan Kavsî, edebî sanatları da başarıyla uygulamıştır. Hayal dünyası geniş ve renklidir. Dili sade, ahenkli ve canlıdır. Samimi ve doğal benzetmelerden, halkın dilindeki güzelliklerden ve deyimlerden yararlanır:

Kimsenüng degmemişem göngline hergiz yā Reb

Yène her kim ki yèter gönglümi vīrān ėyler (G.65/7)

Diller tökerem bülbül ü pervāneye Ḳovsī

Tā bir gün olar hạalumı cānāna dèsünĝler (G.103/5)

Nėy kimi kirdārumuz bendindedür güftārumuz

Kullıg̉a bèl baġlamaġdur kọvlümüz iḳrārumuz (G.212/1)

Gètme başung ședḳesi èy serv-i ḩoş-reftār gel

Gètdüm elden èy dolanım başunga dildār gel (G.296/1)

Öz bābını her kimse her yèrde tapar Ḳovsī

Ben her yana kim gètdüm dīvāneye tuş geldüm (G.313/6)

Şiirin ahengini sağlayan ses ve söz tekrarları için aşağıdaki örneği verebiliriz:

Ne ser-kèş şö‘ledür bu veh bu ne ḳedd ü ne ḳāmetdür

Ḳiyāmetler ḳiyāmından ḳiyām ètmiş ḳiyāmetdür (G.47/1)

Şair, sözcüklerin çokanlamlılığından yararlanır.

Lüṭ ile èy āteşīn-rühssār āb ètdüng beni

Bes ki yüz vèrdüng bu yüzden hem kebāb ètdünĝg beni (G.497/1)

Eş anlamlı ve yakın anlamlı sözcüklerden de yararlanır.

Göngül bir ḳeṭre ḳandur 'ėşk bī-dādın yaşursung mı

Gözüm bir ḳețrede bir behr pinhān ėylemek olmaz (G.215/5)

İżtirābum kẹèd bīminden degül ḳorhum budur

Kim çı̧ha cān olmaya āgāh șeyyādum benüm (G.314/4)

Müjgān dèmeng anga ki men-i sāde oğradum 
Bir çalıcı ḥerāmīye bir egri og̉nya (G.427/3)

Diyerler kim nişān bulmaġ dehānungdan müyesserdür

Ġeleṭdür iftirādur meḥ̇ sözdür bu yalandur bu (G.457/4)

Karşıt anlamlı sözcükleri bolca kullanmıştır.

Sipèhr anung gözini ag èder günini ḳara

Biri ki bildi bu mektebde ag̀ u ḳara nedür (G.176/8)

Ṣebr ü ḳerārum aldı bir ārām-1 cān bu gün

Bir yahşı yāra gönglümi vèrdüm yaman bu gün (G.420/1)

Bugün kullanılmayan pek çok eski sözcük, Kavsî Dîvânında bulunmaktadır:

Menden yaşurma söyle ne mezhebdesen banga

Ėy küfr ü dīn, fireng ü müselmān fedā sanga (G.19-5/5)

Bilmenem kanlu dögünler mi güyür sīnemde

Ya senüng berḳ-‘inānung ayaġınung izidür (G.52/5)

Eger düşmenlere yalvarsa idüm rehm èderlerdi

Bu reng ile ki ben yavuncıdum eḥbāba yalvardum (G.319/7)

Dîvân şiirinde yaygın olduğu gibi, Kavsî’nin şiirlerinde de erkek sevgili tipi hissedilmektedir. Bu tür ilişkide genellikle şâhid-bâzi, nazar-bâzi, cemâl-perestî, bî-rîş, tıfl, tıfl-1 nâz, yalın yüzlü mahbûb, tâze nihâl, civân, sâde, sâde-ruh, muhannes, peser, uşak, oğlan, abdullah, nev-hat, hat, hatt-i rîş, hatt-i izâr, hatt-i sebz (yeşil çizgi, sevgilinin yanaklarında yeni terleyen tüyleri, sakal), sebze-i rîş, sâkî, sâki-gerî, zülf (bayan için genelde gisu kullanılır) gibi sıfatlar kullanılır (Şemisa, 1381).

Dövrinde 'āriżüng heț-i müşkīn gerībdür

N'içün ki āteș üzre reyāḥīn gerībdür (G.55/1)

Kavușandan songra hett āhir benümle kavuşur

Kāş tėz düşsėydi Ḳovsī başa ol re'nā igit (G.29/7)

Lebüng hökmiyle hetț-i sebz teshīi ètdi dünyānı

Feġān kim mūrı ol hāatem Süleymān-1 zamān ètmiş (G.237/3)

Gecçerken rūzgārum sāde-șūretler ḩeyālıyla

Beni Ḳovsī bu me'nīden peşīmān ètdi ol nov-ḩeț (G.244/5)

Tर्शP

Uluslararası Türkçe Edebiyat Kültür Eğitim Dergisi Sayı: 5/4 2016 s. 1773-1804, TÜRKİYE 
Bir uşag̉ung ‘èşḳi ile bilmenem öz adumı

Men ki Eflātūnı tịfl ü ṭifli ustād èylerem (G.375/2)

Bilmenem bilmiş ḳara günlülerüng ḥālın meger

Gẻce tek șübḥ-i bināgūşın siyeh-pūş èyleyen (G.394/7)

\section{KAVSÎ DİVANI'NIN NÜSHALARI}

\section{> Kavsî Dîvânının Elimizde Bulunan Nüshaları}

1. Aşağıdaki 9 nüsha, Mümine Çakır'ın doktora tezini hazırlarken (Çakır, 2008), ilk 4 nüshasını temel alarak yararlandığı nüshalardır.

1.1. Tebriz Millî Ktp. Nüshası: nr. 356, 235 yaprak, nestalik, 13x22, rahmetli Hacı Hüseyin Nahçıvani’ye aitliğini gösteren mührü bulunmaktadır, 1086 (1675) yılında Asker bin Hacı Ali-i Tebrizî tarafindan istinsah edilmiştir (s. 235).

Baş1:

Ėy ètmiş medd-i bismi'llāhdan țug̉rā-yı dīn pẻydā

Anung bir nöḳtesi żimninde Kur’ān-1 mübīn pẻydā (G.1/1)

Sonu:

Bi-hemdi'tlāh ki dūd-1 āhumuz ebr-i bahār oldı

Karadan çıhdı dag̉ u bāg u sehrāā lālezār oldı (TC.3.5/7)

1.2. Tiflis Gürcistan Devlet Ktp. (Elmler Akademisi Kekelidze adına Elyazmaları Enstitüsü) Nüshası: nr. L 51, 195 yaprak, nesih, birinci sayfada 1255 (1838) tarihi var.

Baş1:

Ėy olub Kur’ān-1 è'cāz-āferīn bürhān sanga

Medd-i bismi'llāh, mìzān-1 'ülüvv-i şān sangag (G.2/1)

Sonu:

Bi-ḥemdi'tlāh ki dūd-1 āhumuz ebr-i bahār oldı

Karadan çıhdı dag̉ u bāg u șeḥrā lālezār oldı (TC.3.5/7)

1.3. İstanbul Ün. Ktp. Nüshası: nr.T.5478, 138 yaprak, talik, sonunda 1095 (1683) tarihi var.

Baş1:

Dögünlerüng yėter ėy sebz-reng-i teh gül-gūn

TFkP

Uluslararası Türkçe Edebiyat Kültür Eğitim Dergisi Sayı: 5/4 2016 s. 1773-1804, TÜRKİYE 
Ne gül ne sebze gerekdür ne lālezār banga (G.6/4)

Sonu:

Ḩelḳ içre bu bì-beżā'etüng şöhreti yoh

Bu şehrde eş‘ārı anung oldı 'elem (R.11/2)

1.4. Londra-British Museum Nüshası (ADD 7927): Süleymaniye Ktp.'nde bulunan Mikrofilm nr.3513, 118 yaprak, talik, birinci sayfada 1185 (1771) tarihi var. İkinci sayfada da 1213 (1798) yılında Bağdat şehrinde yazılmış bir temellük kaydı vardır.

Baş1:

Yohdur heberüm kim göngül olmış kime ḥèrān

Āyīne ne bilsüng ser-i bāzār kimünĝdür (G.68/8)

Sonu:

Hẻy hẻy dolanım başunga èy sāḳi-yi yaġı

Öz başung içün koymaya gör elden ayag்1 (TC.2.5/7)

1.5. Ankara Millî Ktp. Nüshası: nr.06 MK YZ.A 3767, 95 yaprak, talik.

Baş1:

Ėy ètmiș medd-i bismi'llāhdan tuggrā-yı dīn pèydā

Anung bir nöḳtesi żimninde Kur’ān-1 mübīn pėydā (G.1/1)

Sonu:

Heberdār olmayan mè'rāc-1 me'nīden ne bilsüng kim

Senüng yèrden göge var imtiyāzung dil-rübālardan (G.396/3)

1.6. Suudi Arabistan Medine Melik Abdülaziz Ktp. (Arif Hikmet Ktp. Mecmuas1)

Nüshası: nr. 811/186, 110 yaprak, nesih.

Baş1:

Ėy ètmiş medd-i bismi'llāhdan țugrāa-yı dīn pèydā

Anung bir nöḳtesi żimninde Kur’ān-1 mübīn pėydā (G.1/1)

Sonu:

Ne huceste mekān ola ol mekān ki yètince șövk-i tamām ile

Ura dāmenin bẻle ḳātilüm, çeke tīginini töke ḳanumı (G.548/2)

Tर्शP

Uluslararası Türkçe Edebiyat Kültür Eğitim Dergisi Sayı: 5/4 2016 s. 1773-1804, TÜRKİYE 
1.7. Bakü Fuzuli Adına El Yazmaları Ktp. Nüshası: nr.B-4366(II), 37 yaprak, nestalik.

Baş1:

Ėy ètmiş medd-i bismi'llāhdan țug̉rā-yı dīn pèydā

Anung bir nöḳtesi żimninde Kur’ān-1 mübīn pèydā (G.1/1)

Sonu:

Ben ėylemenem ‘erż-i temennā sözüm anla

Dindürme beni dilsizem ammā sözüm anla (TB.1.5/9)

1.8. Süleymaniye Ktp. Yazma Bağıșlar Nüshası: nr.3140, 104 yaprak, talik.

Baş1:

Ėdübdür çerh-i müste'cel meni toprag ilen yèksān

Sen ol sėyl-āb-1 bī-zinhārı me'mār ètginen yā Reb (G.25/3)

Sonu:

Benüm tek āyīne baġlardı bin zünnār cövherden

Yüzinde ḥelḳe ḥelḳe ol ḩeț-i tersāyı görsėydi (G.495/6)

1.9. Malatya İl Halk Ktp. Nüshası: nr.252 (daha sonra Konya Bölge Yazma Eserler Ktp. nr.3-252'ye taşınd1), 126 yaprak, talik.

Baș1:

Ne növ‘ Kovvsī-yi mehcūr yanmasung gèceler

Ki her sitāre anga bir şerāredür sensiz (G.202/5)

Sonu:

Günāhum ne dolanım başunga cānān günāhum ne (MH.5.4/5)

\section{2. İran Nüshaları}

2.1. İslam Şura Meclisi I.Ktp. Nüshası: nr.7082, 176 yaprak, nestalik, 19x14, 1141 (1728) yılında Nizameddin Muhammed Bin Hacı Muhammed Salih Dehharkani tarafindan Dehharkan kasabasında istinsah edilmiştir (s.352). Ortalardan birkaç sayfası eksiktir.

Baş1:

Ėy ėtmiş medd-i bismi'llāhdan țuğrā-yı dīn pèydā

Anung bir nöḳtesi żimninde Kur’ān-1 mübīn pèydā (G.1/1)

TF̂R

Uluslararası Türkçe Edebiyat Kültür Eğitim Dergisi Sayı: 5/4 2016 s. 1773-1804, TÜRKIYE 
Sonu:

Olsung binā-yı dövlet-i cāvīiüng üstüvār

Āsūde zilll-i me‘deletünĝde diyārlar (G.559/17)

2.2. Melik Millî Ktp. Nüshası: nr. 4621, 156 yaprak, nestalik, 21x12.8, 1083 (1672) yılında Asker tarafindan istinsah edilmiştir (s.312). Ortalardan birkaç sayfası eksiktir.

Baş1:

...Sülèymān-1 hiredden olmadın nām u nigīn pèydā (G.1/7)

Sonu:

Günāhum ne dolanım başunga cānān günāhum ne (MH.5.5/5)

2.3. Melik Millî Ktp. Nüshası: nr. 5604, nestalik, Türkçe Dîvân kısmı 96 yaprak (s.1191).

Baş1:

Ėy ètmiş medd-i bismi'llāhdan tuggrā-y1 dīn pèydā

Anung bir nöḳtesi żimninde Kưr’ān-1 mübīn pėydā (G.1/1)

Sonu:

Günāhum ne dolanım başuñga cānān günāhum ne (MH.5.5/5)

Başka şairlerin şiirleri de bulunmaktadır. Farsça kısmı 81 yaprak (s.211-372), sonunda 1117 (1705) tarihi var.

Baş1:

İn nemāz çi hāṣil ki nīst kerd ān rā

Ru'ūnetì ki tu rā der ḩemīden īn-cā

Sonu:

Her ki ḩ̌aned du‘ā tẹme‘ dārem

Z'īn-ki men bende-yi güneh-kārem

2.4. Tahran Millî Ktp. Nüshası: nr.5-10833 (f.833), nestalik, 135 yaprak, 1284 (1867) tarihi var. Başından 1 sayfa ve sonundan birkaç sayfa eksiktir.

Baş1:

Gözeller lövḥ-i rühsārında kilk-i șūret-ārāyung

Kilur geh hāal-1 müșkīn gāh hetṭ-i 'enberīn pèydā (G.1/10)

TFip

Uluslararası Türkçe Edebiyat Kültür Eğitim Dergisi Sayı: 5/4 2016 s. 1773-1804, TÜRKIYE 
Sonu:

Peh peh bu ne bülbül bu ne ef gāan ne nevādur (TB.2.5/8)

\section{> Kavsî Dîvânının Bilinen Başka Nüshaları}

1. İran-Tahran Hüseyin Miftah Koleksiyonu Nüshası: nr.1150. Miftah'1n ölümünden sonra bu koleksiyonun birçok el yazma nüshası İslam Şura Meclisi I.Ktp. ve Tahran Millî Ktp.'ne taşındı (Aydın, 2008: 48; Müttakî, 1386: 426; Dânişpejûh, 1353: 163).

2. İran-Kum Ayetullah Gülpaygani Ktp. Nüshası: nr.15/88, 16 yaprak, istinsah tarihi 1249/1833 (Aydın, 2008: 110).

3. Pakistan Dânişgâh-i Pencab Nüshası: nr. 699 pi VI 165 (572 f), nestalik, 1882.

Baş1: Ey Katre-i ze Feyż-i to cān-i mā (Münzevî, 1350: 2488).

4. İngiltere Oxford-Bodleian Ktp. Türkçe yazmaları Nüshası: nr.MS Turk.d.10, 162 yaprak, talik (“yazar adı: Kavsî”, (Çevrimiçi) https://www.yazmalar.gov.tr, 2011).

5. İstanbul-Murad Molla Ktp. Arif Hikmet Bey arşivi nr.3665 ile kayıtlı ve 190 yaprak olduğu söylenen nüsha (Karabulut, 2001: 2394, 4055).

6. Almanya Nüshası: Hamîde Reiszâde'nin yalnız ilk ve son sayfasını verdiği ve başka hiçbir bilgi vermediği Almanya nüshası (Reiszâde, 1376).

7. Terbiyet Nüshası: Muhammet Ali Terbiyet, elinde Kavsî’nin Farsça ve Türkçeden oluşan 6000 beyitlik bir Dîvânının bulunduğunu söylese de, bugün bu Dîvânın nerede olduğu belli değildir (Terbiyet, 1314: 310-311).

8. Köçerli Nüshası: Feridun Bey Köçerli'nin elinde bulunan Kavsî Dîvânının bugün nerede olduğu belli değildir (Köçerli, 1925: 175-187).

Yukarıda sıraladığımız bu nüshalardan başka, Mümine Çakır'dan -fazla bilgisi olmamakla birlikte- Irak'ta da Kavsî Dîvânının olduğunu ve hatta bu konuda tez çalışmalarının yapıldığını öğrendik. Geniş bir coğrafyada yayılan Kavsî Dîvânının nüshaları, onun ne denli ünlü bir şair olduğunu göstermek açısından önemlidir.

İstanbul nüshası, Dîvânın aslına yapılan değiştirmeler ve yanlışlarla dolu olduğu için güvenilir değildir. Dolayısıyla, bu nüshanın esas alınması doğru olmaz. Ancak İstanbul nüshasında, başka nüshalarda olmayan birçok gazel bulunmaktadır.

Londra nüshasında da, Kavsî Dîvânının aslından kısmen sapmalar görülmektedir. Daha vahimi; bu nüshada geçen birçok Türkçe sözcük, yabancı sözcüklerle değiştirilmiştir (örneğin: özge > gèyri, ķıraġa > kenāra). 
İran nüshalarından Tahran/Melik 5604 numaralı nüshada, Kavsî Dîvânından seçmeler yapılmıştır. Tahran Millî Ktp. nüshası, daha çok önem taşımaktadır. Bu nüsha, Dîvânın daha da hacimli olabileceğini göstermektedir çünkü bu nüshada, diğer nüshalarda bulunmayan birçok beyit ve 5 gazel daha bulunmaktadır. Ancak bu nüshada da, gazellerin hepsi bulunmayıp bir seçme sözkonusudur. Bu nüshanın başından bir sayfa ve sonundan da birkaç sayfa eksiktir.

Tahran/Melik 4621 numaralı nüsha, güzel bir nestalik yazısıyla yazılmıştır. Ortalardan birkaç sayfası eksiktir. Aynı şekilde, Tahran/Meclis nüshası da böyle eksiktir. Bu nüshada, diğer nüshalarda bulunmayan 2 gazel daha bulunmaktadır.

\section{Sonuç}

XVII. yüzyılın ikinci yarısında yaşayan Tebrizli Kavsî, Azerbaycan edebiyatının önemli şairlerindendir. Bazı araştırmacıların sandığı gibi, adı Alican değildir. Kavsî-i Tebrizî’nin adı; Sâ’ib-i Tebrizî’nin Beyaz'1, Tezkire-i Nasrabadî, Seyyid Azim Şirvanî Tezkiresi ve Muhammet Ali Terbiyet'in Dânişmendân-1 Azerbaycan'ı gibi eserlerde geçmektedir.

Kavsî’nin hacimli ve çoğu gazellerden oluşan Türkçe Dîvânında; toplam 4891 beyitten oluşan 559 gazel, 2 terkib-i bend, 3 terci-i bend, 7 müseddes, 5 muhammes, 14 murabba ve 12 rubai bulunmaktadır. Yani bizim çalışmamızdaki metin, Dîvâna dair son çalışma olan M. Çakır'ın metnine göre önceki gazeller içinde 82 ek beyit, 59 beyitten oluşan 7 ek gazel, bir ek rubai yani toplam 143 beyit daha fazla şiir içermektedir. Eklediğimiz bu şiirler, 4 yeni nüshaya (Tahran/Meclis, Tahran/Melik 4621, Tahran/Melik 5604 ve Tahran Millî Ktp. nüshalarına) ulaşmamızla mümkün olmuştur.

\section{Kaynaklar}

AKPINAR, Y. (1982a). Azerî. Türk Dili ve Edebiyatı Ansiklopedisi, I. İstanbul: Dergah yay.

AKPINAR, Y. (1982b). Kavsî-i Tebrizî, Alican. Türk Dili ve Edebiyatı Ansiklopedisi, V. İstanbul: Dergah yay.

AKPINAR, Y. (2002). Kavsî-i Tebrizî. Íslam Ansiklopedisi, XXV. Ankara: TDV yay.

AKPINAR, Y. (1994). Azeri Edebiyatı Araştırmaları. İstanbul: Dergah yay.

ARASLI, H. (1998). Azerbaycan Edebiyatı Tarihi ve Problemleri. Bak1, s. 569-586.

ARASLI, H., GULUZADE, M., CAFEROV, M. C., (1960). Azerbaycan Edebiyatı Tarihi, I. Bak1: Azerbaycan SSR İlimler Akademiyası.

AYDIN, Ş. (2008). İran Kütüphanelerinde Türkçe Yazmalar Kataloğu. İstanbul: Timaş yay.

Azerbaycan Sovet Ansiklopediyasi, “Qövsi”, III (1979). Bakü.

BAHADIR, Nevvâb Sadîk Hasan Han (ş. 1386). Tezkire-i Şem'-i Encümen. yay.haz.: Dr. Muhammed Kazim Kehdui. Dânişgâh-i Yezd yay. 
BAYRAM, Ö. (2005). Azerbaycan Sahası Tezkireleri ve Seyyid Azim Şirvanî’nin Tezkiresi. Yayınlanmamış Doktora Tezi. Ankara: Gazi Üniversitesi Sosyal Bilimler Enstitüsü Türk Dili ve Edebiyatı Anabilim Dalı.

BEGDİLI, Lutfali Beg Azer (ş. 1337). Ateşkede-i Azer. yay.haz.: Seyyid Ca’fer-i Şehidi. Tahran: Müessese-i Neşr-i Kitab yay.

CAFEROĞLU, A. (1953). Azerbaycan Dili ve Edebiyatının Dönüm Noktaları, II. Ankara: Azerbaycan Kültür Derneği yay.

CELAL, Mir, Firidun Hüseynov. (2000). Örnekleriyle XX. Asır Azerbaycan Edebiyatı. yay.haz.: K. Yavuz, E.Ülgen. İstanbul: Birleşik Yayıncılık.

ÇAKIR, M. (2008). Kavsi, Hayatı, Edebi Kişiliği ve Divanı (inceleme-tenkitli metin-dizin). Yayınlanmamış Doktora Tezi, Ankara: Gazi Üniversitesi Sosyal Bilimler Enstitüsü Türk Dili ve Edebiyatı Anabilim Dalı.

DAĞISTANÎ, AliKulı Vale. (ş. 1384). Tezkire-i Riyâzu'ş-Şu'arâ, III: Revza-i Kaf. yay.haz.: Muhsin Naci Nasrabadî. Tahran: Esatir yay.

DÂNIŞPEJÛH, Muhammed Takî, EFŞAR, İrec. (ş. 1353). Nüshahâ-ı Hattî: Defter-i Heftom. Tahran: Dânişgâh-i Tahran yay.

DEVLETABADÎ, A. (ş. 1370). Serâyendigân-i Şiir-i Fârsî Der Kafkas. Tahran: Bünyad-i Mevkufat-i Dr. Mahmud Ef̧̧ar.

DEVletaBADÎ, A. (ş. 1377). Sühanverân-i Azerbaycan: Ez Katrân Tâ Şehriyâr. Tebriz: Sütude yay.

DEYHİM, M. (ş. 1367). Tezkire-i Şu 'arâ-yı Azerbaycan, II. Tebriz.

ERTAYLAN, İ. H. (1928). Azerbaycan Edebiyatı Tarihi, I-II. Bakü: Azer Neşr.

HAYYAMPUR, A. (1340). Ferheng-i Sühanverân. Tebriz.

HEMRAZ, R. (ş. 1389). Incelikler Şairi Tebrizli Kavsî. (Çevrimiçi) http://www.rezahamraz.com/fa/index.php?option=com_content\&task=view\&id=258\&It emid=2

HEY'ET, C. (ş. 1376). Azerbaycan Edebiyatı Tarihine Bir Bakış. Tahran.

HİDÂYET, M. Gülzâr-i Câvîdân, II.

KAFKASYALI, A. (2002). İran Türk Edebiyatı Antolojisi, I-II. Erzurum: Atatürk Üniversitesi yay.

KARABULUT, A ve KARABULUT, A.T. (2001). Mucemu't-Tarihu't-Turâsü'l-İslami fi Mektebati'l- 'Âlem. Kayseri: Mektebe yay.

KAŞANÎ, Takiye'd-din Muhammed bin Şerefe'd-din Ali Hüseynî, Hulâsatu'l-Eş 'âr ve Zübdetü’l-Efkâr (yazma eser), İran Meclis Kütüphanesi, nr.334.

Kavsî, Dîvân. Bakü Fuzuli Adına El Yazmaları Ktp., nr. B-4366 (II)

......., Dîvân. İran-Tahran İslam Şura Meclisi I.Ktp., nr.7082.

........, Dîvân. İran-Tahran Melik Millî Ktp., nr. 4621.

........, Dîvân. İran-Tahran Melik Millî Ktp., nr. 5604.

, Dîvân. İran-Tahran Millî Ktp., nr.5-10833 (f.833).

, Dîvân. İran-Tebriz Millî Ktp., nr. 356.

Dîvân. İstanbul Ün. Ktp., nr.T.5478. 
Dîvân. Londra-British Museum (ADD 7927), Süleymaniye Ktp.'nde bulunan Mikrofilm nr.3513.

Dîvân. Suudi Arabistan Medine Melik Abdul'l-aziz Ktp. (Arif Hikmet Ktp. Mecmuas1), nr. 811/186.

Dîvân. Tiflis Gürcistan Devlet Ktp. (Elmler Akademisi Kekelidze adına Elyazmaları Enstitüsü), nr. L 51.

, Dîvân. Türkiye-Malatya İl Halk Ktp., nr.252 (daha sonra Konya Bölge Yazma Eserler Ktp. nr.3-252'ye taşınd1).

, Dîvân. Türkiye-Süleymaniye Ktp. Yazma Bağışlar, nr.3140.

KERBELÂ̂, Hafiz Hüseyin. (ş. 1383). Revzâtü'l-Cinân ve Cennâtü'l-Cinân. yay.haz.: Cafer Sultanu'l-Kurâî. Tebriz: Sütude yay.

KERIMÎ, M. R. (ş. 1384). Azerbaycan Edebiyat Tarihi, II. Zencan: Yekta Resed yay.

KERIMOV, P. (2009). Ali Şir Nevayi ve XVII. Yüzyıl Azerbaycan Lirik Şiiri. Hacettepe Ün. Türkiyat Araştırmaları. Ankara, 10, 57-67.

KERIMOV, P, HÜSEYNİ, M. A. (2008). XVII Asr Azerbaycan Lirikası (Antologiya). Bakü: Nurlan.

KERIMOV, P. (2005). Qövsi Tebrizi Divan. Bakü: Nurlan.

KÖÇERLİ, Feridun Bey. (1925). Azerbaycan Edebiyatı Tarihi Materyalleri, I. Bakü: Azer Neşr.

KÖPRÜLÜ, M. F. (1979). Azeri. İslam Ansiklopedisi (MEB), II: 118-151.

LUCKNOWÎ, A. R. (ș. 1361). Riyâzu'l-'Arifîn, II. yay.haz.: Seyyid Hisame'd-din Raşidi. Lahur: Merkez-i Tahkikât-i Fârsî İran ve Pakistan.

MUHTAROĞLU, V. (1992). Türkiye Dışındaki Türk Edebiyatları Antolojisi, I. Ankara: Kültür Bakanlığı yay., s.151.

MÜMTAZ, S. (1925). Azerbaycan Edebiyatı: Kavsî. Say1 5, Bakü: Komünist yay.

MÜNZEVÎ, A. (ş. 1350). Fihrist-i nüshahâ-ı hattî-i Fârsî, III. Tahran: Müessese-i Ferheng-i Mintıkai.

MÜTTAKÎ, H. (ş. 1386). Kitabşinâsi-i Fehâris, I. Kum.

NAİNî, M. A. M. (ş. 1376). Tezkire-i Medinetü'l-Edeb. Kitaphane ve Müze ve Merkez-i Esnadi Meclis-i Şura-yı İslami.

NASRABADÎ, M. M. T.. (ş. 1361). Tezkire-i Nasrabadî. yay.haz.: Vahid-i Destgirdi.Tahran: kitabfuruşi-i furugi.

NEVÂ̂̂,, Ali Şir. (2001). Mecâlisü’n-Nefâyis: (giriş ve metin). yay.haz.: Kemal Eraslan. Ankara: TDK yay.

NEVÂ̂̂,, Ali Şir. (ş. 1363). Tezkire-i Mecâlisü’n-Nefầis. yay.haz.: Ali Asgar Hikmet. Tahran: Kitabfuruşi-i Menuçehri yay.

NURU'L-HASAN, Nigâristân-i Sühan, Dânişgâh-i Tahran Merkez Kütüphanesi (yazma eserin fotokopisi), nr.7218.

ÖZTEKİN, Ö. (2010). Çelebizâde Âsım Divan. Ankara: Ürün Yayınları.

PİRVERDİĞLU, A. (2002). Türkler, XIX. editör: Hasan Celal Güzel, Kemal Çiçek, Salim Koca. Ankara: Yeni Türkiye yay.

REİSZÂDE, S. H. (ş. 1376). Dîvân-ı Kavsî. Tahran. 
RIEU, C. (2008). Biritiş Müzesindeki Azeri Eserleri (çeviren: Mebrure Rahmi). Azerbaycan Yurt Bilgisi (Tipkı Basım), III. Ankara: TDK yay.

RIEU, C. (1978). Catalogue Of The Turkish Manuscripts In The British Museum. Osnabrück: Otto Zeller Verlag.

RÜSTEMOVA, A. (2004). Türk Dünyası Edebiyat Tarihi, VI. Ankara: Atatürk Kültür Merkezi Başkanlığ 1 yay.

SABA, M. M. H. (ş. 1343). Tezkire-i Rûz-i Rûşen. yay.haz.: Muhammet Hüseyin Rüknzâde Ademiyyet. Tahran: Kitabhane-i Razi yay.

SAFERLİ, Aliyar, Halil Yusuflu. (ş. 1376). Azerbaycan Edebiyatı Tarihi, I. çeviren: Hüseyin Şarki (Soy Türk). Tahran: Rastan yay.

SAFERLİ, Aliyar, Halil Yusuflu. (1992). Türkiye Dışındaki Türk Edebiyatları Antolojisi, II. Ankara: Kültür Bakanlığı yay.

SAFEVÎ, Sâm Mirza. (ş. 1384). Tuhfe-i Sâmî, yay.haz.: Rüknü'd-din Humayunfer. Tahran: Esatir yay.

Sâmî, Şemseddin. (1893). Kâmusü’l-A 'lam, I-VI. İstanbul: Mehran Matbaas1.

SEYİDOV, M. (1963). Qövsi Tebrizi. Bakı: Azerbaycan SSR İlimler Akademiyası yay.

SULTANU'L-KURRÂ̂̂I, M. E. (1389). Kavsî-i Tebrizî $\hat{I} n$ yâ Ân. (Çevrimiçi) http://www.rezahamraz.com/fa/index.php?option=com_content\&task=view\&id=328\&It emid=2

SÜNBÜHLÎ, Mir Hüseyin Dost. (1292). Tezkire-i Hüseynî. Lucknow.

ŞEMISA, S. (ş. 1381). Şahid-bazi Der Edebiyat-i Fârsî. Tahran: Firdevs yay.

TAHRANÎ, Aga Büzürg. (1970). Ez-Zeria ila Tasanifi’ş-Şi‘a, IX (3. Kısım). Beyrut.

TERBIYET, M. A. (ş. 1314). Dânişmendân-ı Azerbaycan. Tebriz.

TUMAN, M. N. (2001). Tuhfe-i Nailî, II. yay.haz.: Cemal Kurnaz, Mustafa Tatçı. Ankara: Bizim Büro yay.

Türkçe Sözlük (2005). Ankara: TDK yay.

(Çevrimiçi) https://www.yazmalar.gov.tr, “yazar adı: Kavsî” (2011). 


\section{EKLER}

(İran Nüshalarının Birinci Sayfası)

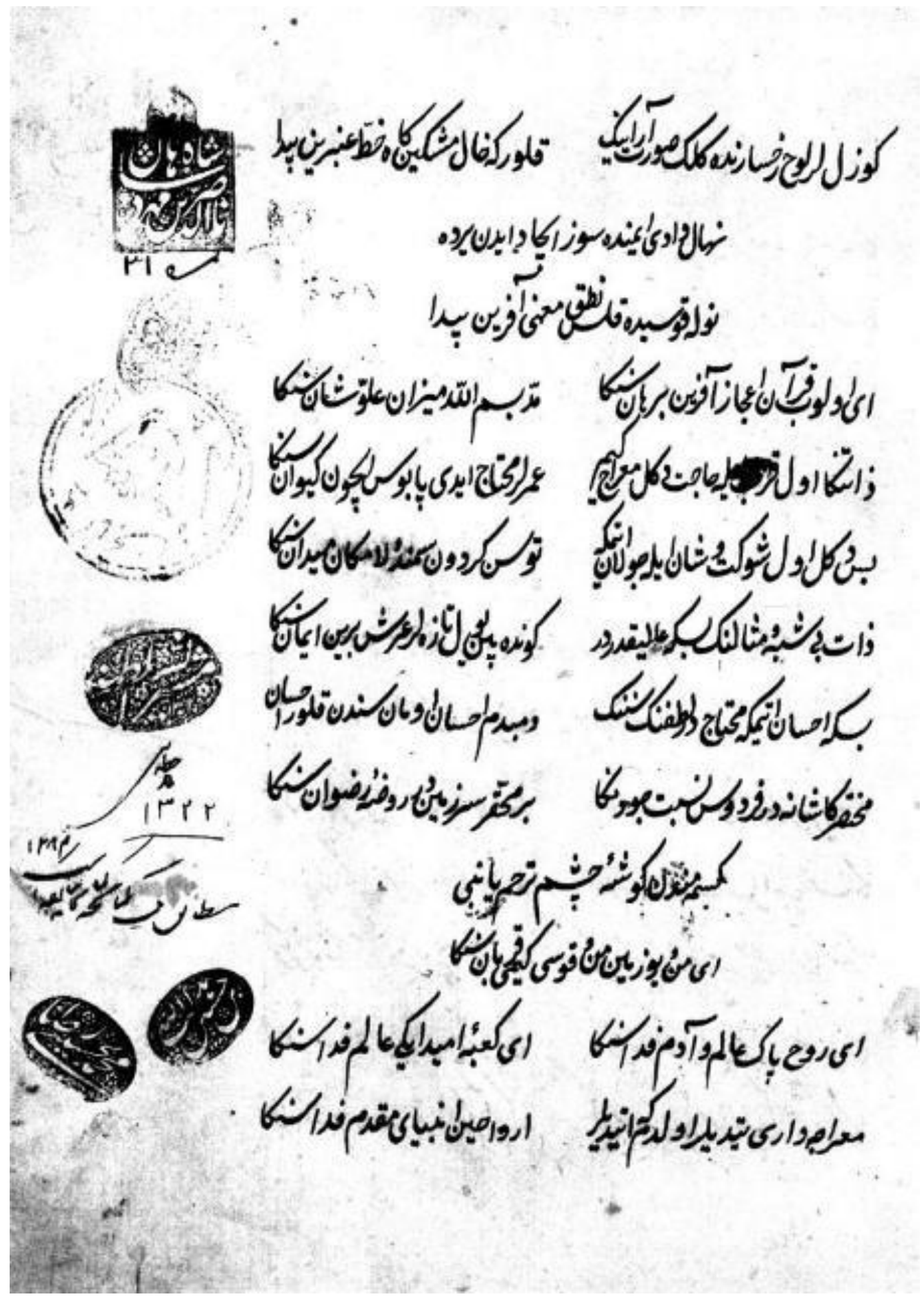

Tahran Millî Ktp. Nüshas1, nr.5-10833 (f.833), S.1 


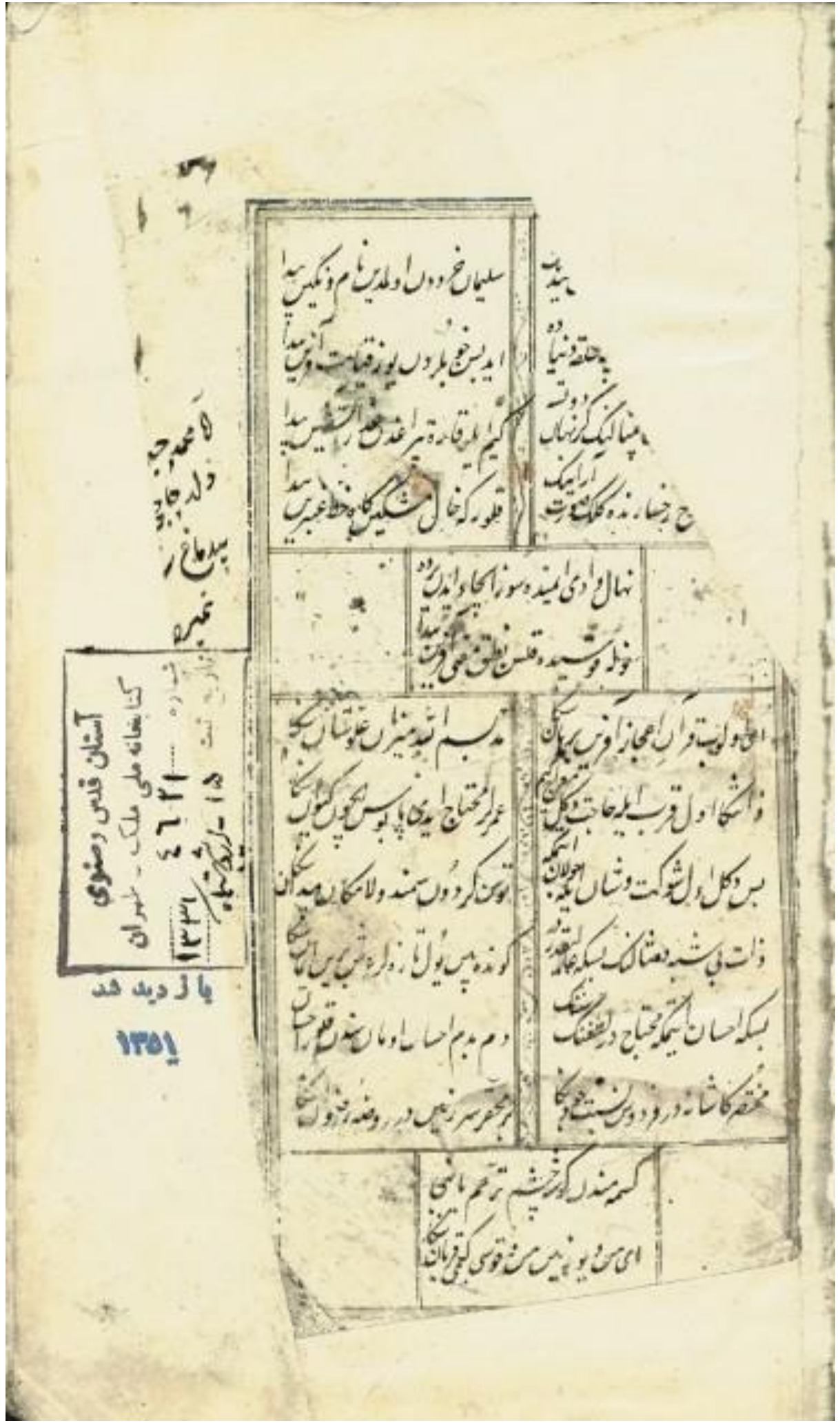

Melik Millî Ktp. Nüshası: nr. 4621, S.1 


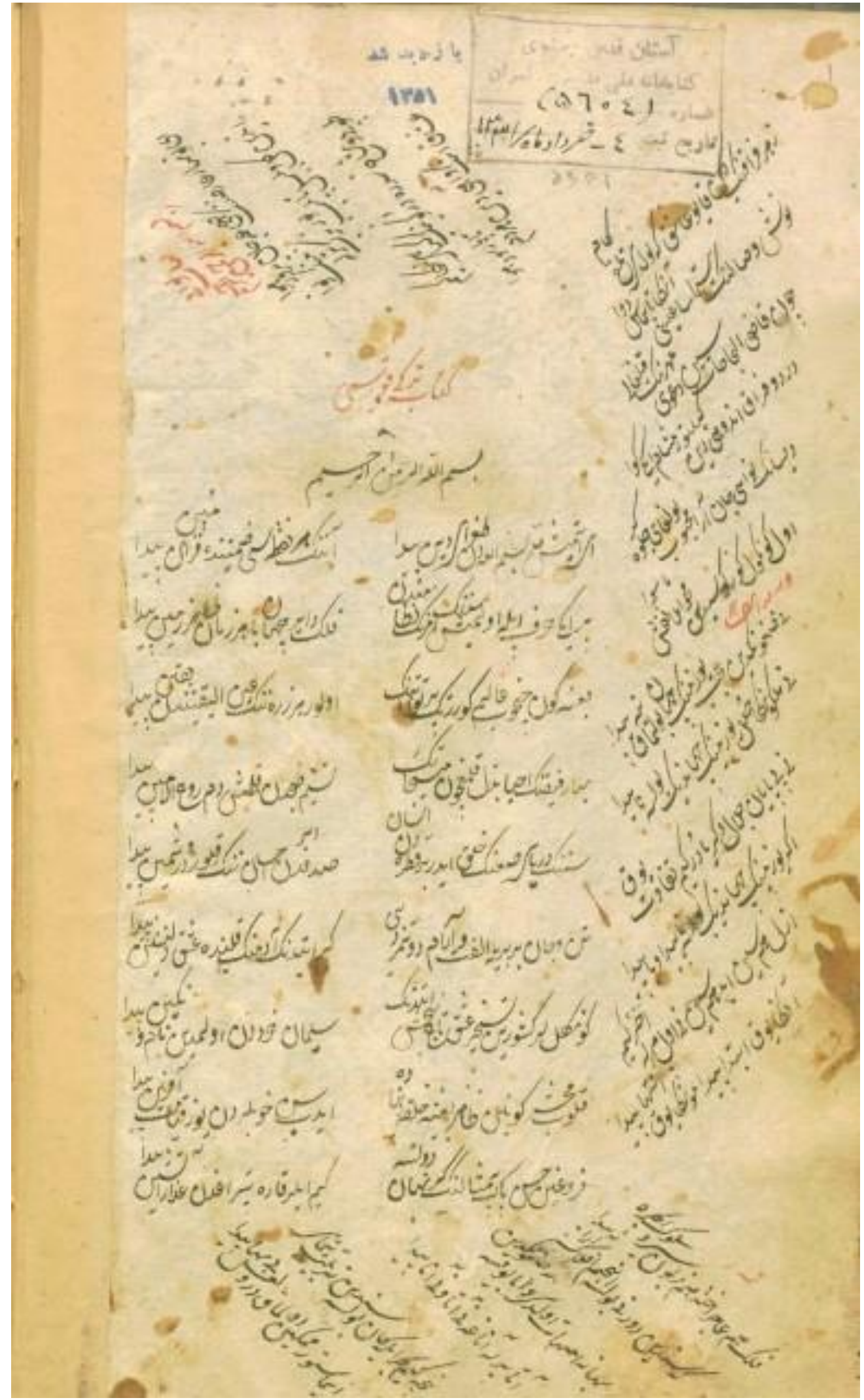

Melik Millî Ktp. Nüshası, nr. 5604, S.1 


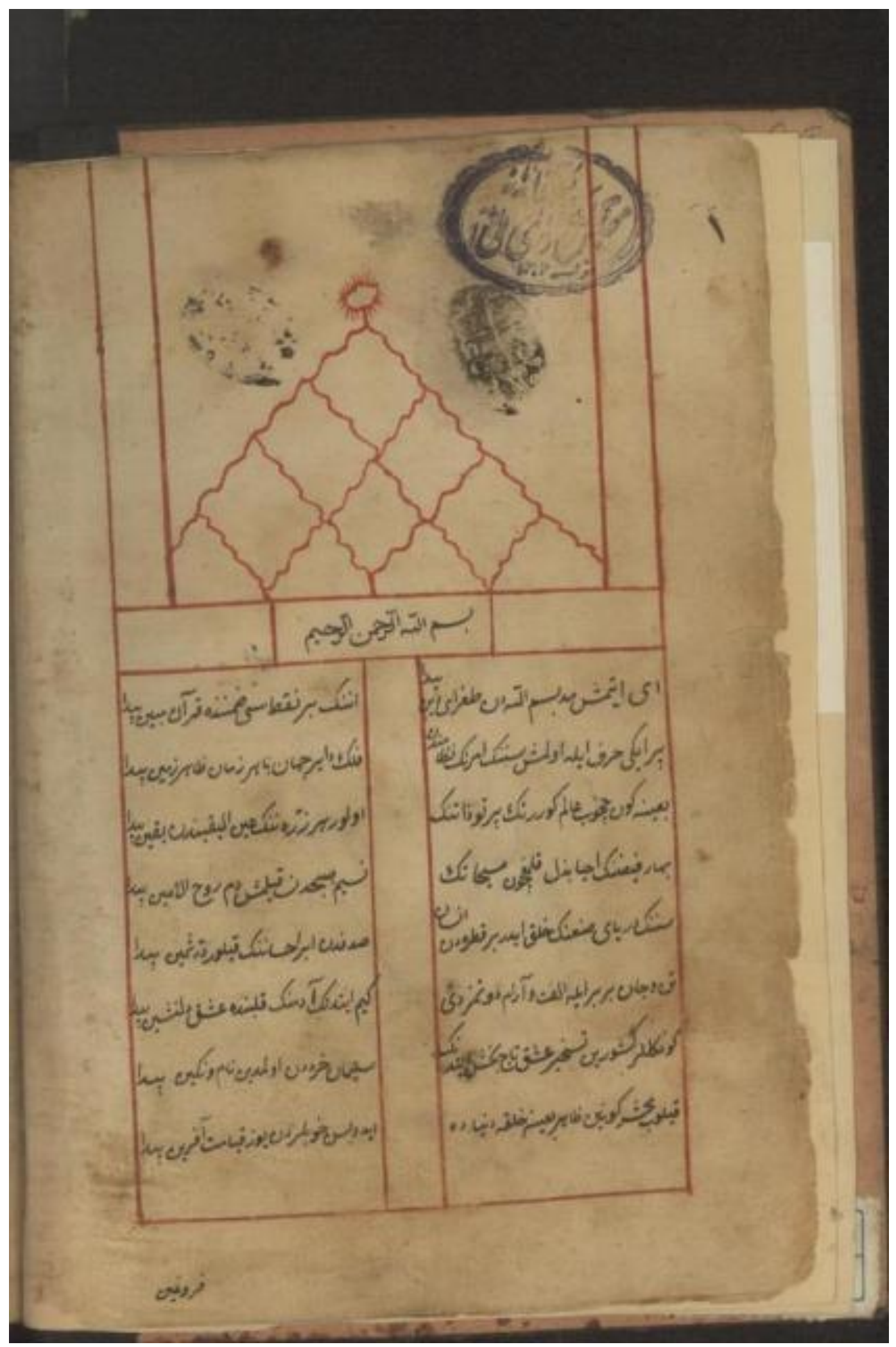

İslam Şura Meclisi I.Ktp. Nüshas1, nr.7082, S.1 


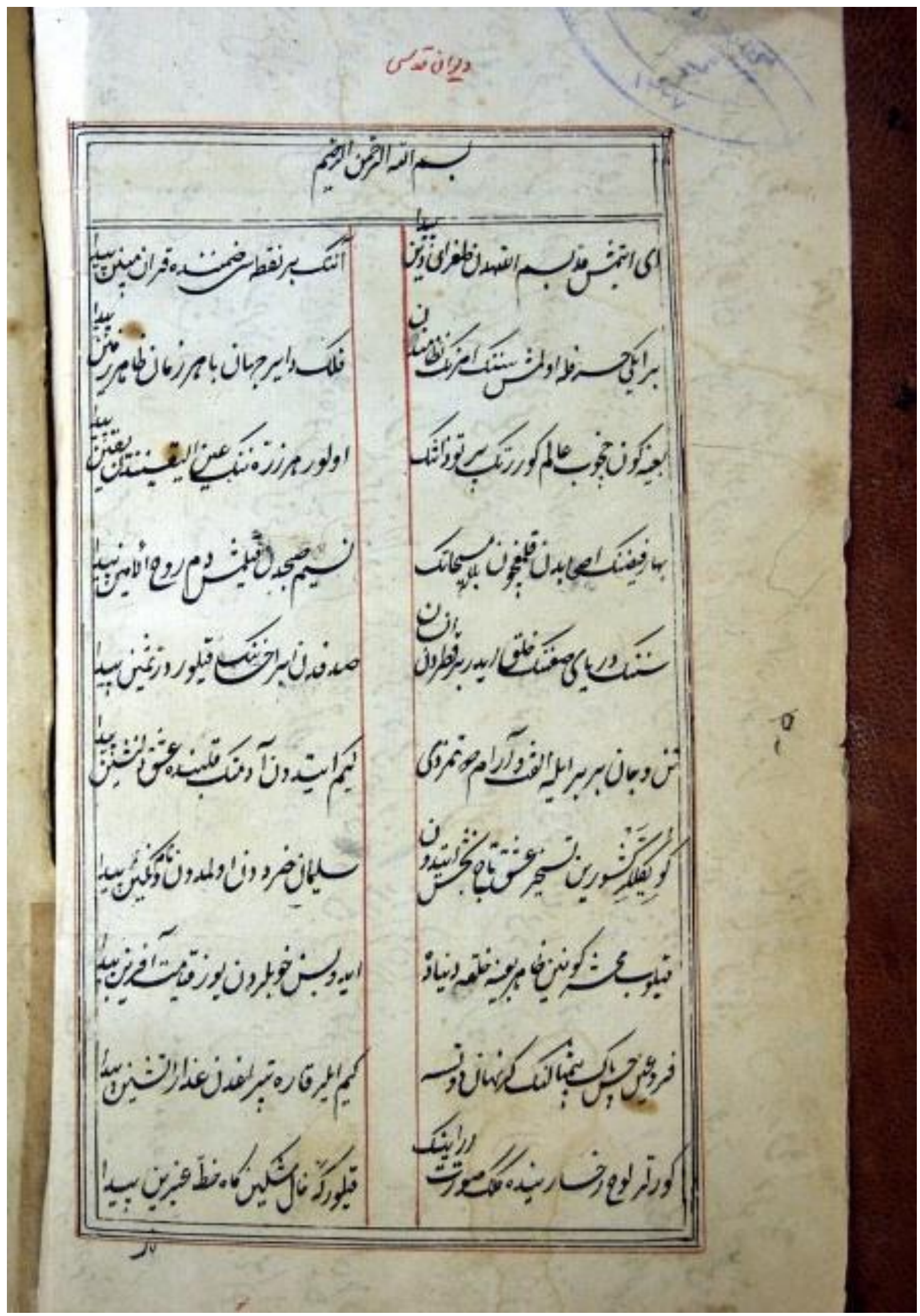

Tebriz Millî Ktp. Nüshası, nr. 356, S.1 